Review

\title{
The Mitochondrial Basis of Aging and Age-Related Disorders
}

\author{
Sarika Srivastava \\ Virginia Tech Carilion Research Institute, 2 Riverside Circle, Roanoke, VA 24016, USA, \\ Sarika_Srivastava@vtc.vt.edu; Tel.: +1-540-526-2047 \\ Academic Editors: Konstantin Khrapko and Dori Woods \\ Received: 31 October 2017; Accepted: 13 December 2017; Published: 19 December 2017
}

\begin{abstract}
Aging is a natural phenomenon characterized by progressive decline in tissue and organ function leading to increased risk of disease and mortality. Among diverse factors that contribute to human aging, the mitochondrial dysfunction has emerged as one of the key hallmarks of aging process and is linked to the development of numerous age-related pathologies including metabolic syndrome, neurodegenerative disorders, cardiovascular diseases and cancer. Mitochondria are central in the regulation of energy and metabolic homeostasis, and harbor a complex quality control system that limits mitochondrial damage to ensure mitochondrial integrity and function. The intricate regulatory network that balances the generation of new and removal of damaged mitochondria forms the basis of aging and longevity. Here, I will review our current understanding on how mitochondrial functional decline contributes to aging, including the role of somatic mitochondrial DNA (mtDNA) mutations, reactive oxygen species (ROS), mitochondrial dynamics and quality control pathways. I will further discuss the emerging evidence on how dysregulated mitochondrial dynamics, mitochondrial biogenesis and turnover mechanisms contribute to the pathogenesis of age-related disorders. Strategies aimed to enhance mitochondrial function by targeting mitochondrial dynamics, quality control, and mitohormesis pathways might promote healthy aging, protect against age-related diseases, and mediate longevity.
\end{abstract}

Keywords: mitochondria; mitochondrial dysfunction; aging; reactive oxygen species; mitochondrial dynamics; mitophagy; mitochondrial biogenesis; age-related disorders

\section{Introduction}

Aging is broadly defined as a time-dependent gradual and progressive decline in living organisms cellular and organ functions leading to increased vulnerability to chronic diseases and death [1,2]. Nine candidate hallmarks of mammalian aging have recently been identified and classified under three categories i.e., the primary hallmarks (genomic instability, telomere attrition, epigenetic alterations, and loss of proteostasis), the antagonistic hallmarks (mitochondrial dysfunction, deregulated nutrient sensing and cellular senescence), and the integrative hallmarks (stem cell exhaustion and altered intercellular communication) [2]. The primary hallmarks are underlying cause of molecular damage during aging, the antagonistic hallmarks exert beneficial or protective effects at low levels but are deleterious to the organism at high levels, and the integrative hallmarks arise when the cellular homeostatic mechanisms fail to compensate for the accumulating damage [2,3]. Importantly, the aging hallmarks interconnect and impinge upon cellular metabolism, thus targeting metabolism may be a promising strategy towards extending human healthspan and lifespan [3].

Mitochondria are central to regulating cellular metabolism and homeostasis due to their key roles in bioenergetics, generation of reactive oxygen species (ROS), anabolism and catabolism, iron-sulfur cluster and heme biosynthesis, calcium and iron homeostasis, apoptosis and signal 
transduction [4-8]. These organelles are vital for life, dynamic and reprogram metabolism in response to cellular stress [5,9]. Mitochondrial dysfunction is linked to various aspects of aging including impaired oxidative phosphorylation (OXPHOS) activity, increased oxidative damage, decline in mitochondrial quality control, reduced activity of metabolic enzymes, as well as changes in mitochondrial morphology, dynamics and biogenesis $[10,11]$. Mitochondrial dysfunction is also implicated in numerous age-related pathologies including neurodegenerative and cardiovascular disorders, diabetes, obesity and cancer [7,8,12-18]. The maintenance of mitochondrial and cellular homeostasis requires a tight regulation and coordination between generation of new and removal of damaged mitochondria. The damaged or dysfunctional mitochondria are selectively degraded by a mitochondria-specific autophagy clearance process known as mitophagy, whereas new mitochondria are synthesized by mitochondrial biogenesis. An intricate regulatory network balances the mitophagy and mitochondrial biogenesis processes, thus proper coordination of these two opposing processes is critical for aging and longevity [19-21]. Dysfunctional or stressed mitochondria generate signals that trigger activation of mitochondrial-to-nuclear, mitochondrial-to-cytosolic, and non-cell-autonomous responses that act to protect against cell death, and restore cellular and metabolic homeostasis [9,22,23]. Here, I will provide a comprehensive overview on the role of mitochondrial DNA (mtDNA) mutations, ROS, oxidative stress, mitochondrial fission, fusion, biogenesis and turnover pathways in aging. Further, I will discuss the emerging evidence that an imbalance between mitochondrial fission and fusion as well as mitochondrial degradation and biogenesis pathways contribute to the pathogenesis of various age-related disorders. Therapeutic strategies that improve mitochondrial dysfunction by targeting mitochondrial dynamics, quality control and stress response-mediated mitohormesis pathways may benefit humans in terms of healthy aging, protection against age-related diseases, and longevity.

\section{Mitochondria, Aging and Age-Associated Pathologies}

Mitochondria are vital for life as these organelles serve as the powerhouse or energy currency of the eukaryotic cells. Mitochondria generate energy or adenosine triphosphate (ATP) by breakdown of fuel (i.e., glucose and fatty-acids) through a series of redox reactions performed by a set of five electron transport chain (ETC) enzyme complexes of the mammalian OXPHOS system [24]. The role of mitochondria in aging was first proposed more than 40 years ago by Denham Harman, who postulated the free radical theory of aging, suggesting that accumulation of cellular damage with increasing age results from reactive oxygen species (ROS) and mitochondria are one of the most important sources and targets of ROS that could function as an 'aging clock' $[25,26]$. Since then, a growing body of evidence has shown that mitochondrial dysfunction contributes to aging in multiple model organisms and that several factors cause increased mitochondrial dysfunction with chronological age including accumulation of somatic mtDNA mutations, enhanced oxidative damage, decreased abundance and quality of mitochondria, as well as dysregulation of mitochondrial dynamics as discussed below.

\subsection{Somatic Mitochondrial DNA Mutations}

Mitochondria are unique as they harbor their own genome (mtDNA), which in humans is $\approx 16,569$ base pairs (bp) double-stranded circular molecule containing 37 genes that encode 13 messenger RNAs (mRNAs), 22 transfer RNAs (tRNAs) and 2 ribosomal RNAs (rRNAs) [24]. Point mutations and deletions are the two most frequent types of mutations that arise in mtDNA genome with age mainly due to spontaneous errors during mtDNA replication or damage repair. A wealth of supportive evidence demonstrates that mitochondrial dysfunction occurs with age due to accumulation of mtDNA mutations (Figure 1); however, the causative role of mtDNA mutations in aging remains controversial. Various mtDNA point mutations have been shown to significantly increase with age in the human brain, heart, skeletal muscles and liver tissues [27-32]. Increased frequency of mtDNA deletions/insertions have also been reported with increasing age in both animal models and humans [33,34]. MtDNA deletion mutations were shown to accumulate intracellularly to high levels in aged human skeletal 
muscle fibers and associate with segmental ETC abnormalities, fiber atrophy, splitting and enhanced oxidative damage leading to sarcopenia [35,36]. Accumulation of mtDNA 4977 bp deletion (common deletion) was also shown to occur with increasing age (from 39 to 82 years) in different brain regions of normal human adults [37]. The age-associated mosaic respiratory chain deficiency in the forebrain of a chimeric mouse that harbored a mixture of normal and respiratory chain-deficient neurons revealed that low proportion $(>20 \%)$ of ETC deficiency was sufficient to induce neuronal mitochondrial dysfunction and neurological disease [38]. Moreover, an increase in the number of neurons with cytochrome c oxidase (COX) deficiency was reported in the substantia nigra and hippocampus of normal human aging brains indicating that complex IV defects significantly increase with age causing mitochondrial dysfunction $[32,39,40]$. Loss of COX activity was also reported to occur physiologically with age in various other tissues including heart, skeletal muscles, diaphragm and colonic crypt stem cells further supporting a role of mitochondrial dysfunction in aging [29,30,41]. The strongest evidence to date that favors a causative role of mtDNA mutations in aging comes from the study of mtDNA mutator mice that express a proofreading exonuclease activity deficient version of mtDNA polymerase $\gamma\left(\right.$ Polg $\left.{ }^{\mathrm{mut} / \mathrm{mut}}\right)$ and exhibit significant accumulation of mtDNA mutations as well as premature or accelerated aging phenotype [42,43].

Although accumulation of somatic mtDNA mutations has been implicated as a causal factor in aging by numerous studies, there are multiple conflicting reports raising the controversy whether mtDNA mutations accumulate to sufficiently high levels with age to establish their causative role in the aging process $[27,44,45]$. MtDNA exists in multiple copies (i.e., hundreds to thousands) per cell and based on the phenotypic expression threshold the mtDNA mutation load (or heteroplasmy) exceeding a critical threshold (i.e., $>60-80 \%$ heteroplasmy based on the type of mutation) would lead to mitochondrial dysfunction and disease expression [46]. Notably, the abundance of mtDNA mutations rarely exceeds $\approx 1 \%$ with age in normal human adults which is well below the phenotypic expression threshold $[32,47]$. The idea that $\mathrm{mtDNA}$ deletions cause aging and age-related diseases was previously contradicted by the study of mito-mice harboring $\approx 4.7 \mathrm{Kbp}$ mtDNA deletion uniformly distributed among various tissues and showing that an accumulation of up to $\approx 60 \% \mathrm{mtDNA}$ deletion in different tissues displayed no signs of mitochondrial dysfunction and disease manifestation, whereas tissues with $>85 \%$ mtDNA deletion exhibited mitochondrial dysfunction and disease phenotypes $[48,49]$. Another study that strongly argued against the possible role of mtDNA mutations in the aging process employed a highly sensitive random mutation capture assay to show that mtDNA mutation frequency in the brain and heart tissues of wild-type aged mice was $\approx 10$ times lower than previously reported, which is in striking contrast to the mtDNA mutation load that is $\approx 500$-fold higher in mtDNA mutator heterozygous mice (Polg ${ }^{\mathrm{mut} /+}$ ) that exhibit a normal life span and no signs of premature aging [50]. However, the caveats of this study are that their assay did not detect any large-scale mtDNA deletions which have been shown to accumulate in the aged human tissues and that any species-specific differences could not be ruled out which may causally relate mtDNA mutations to aging in humans $[40,44]$. Further studies are required to clarify any species-specific differences in somatic mtDNA mutation accumulation during aging and to determine whether relatively lower mtDNA mutation frequency reported in aged mice may be functionally relevant or irrelevant for human aging. 

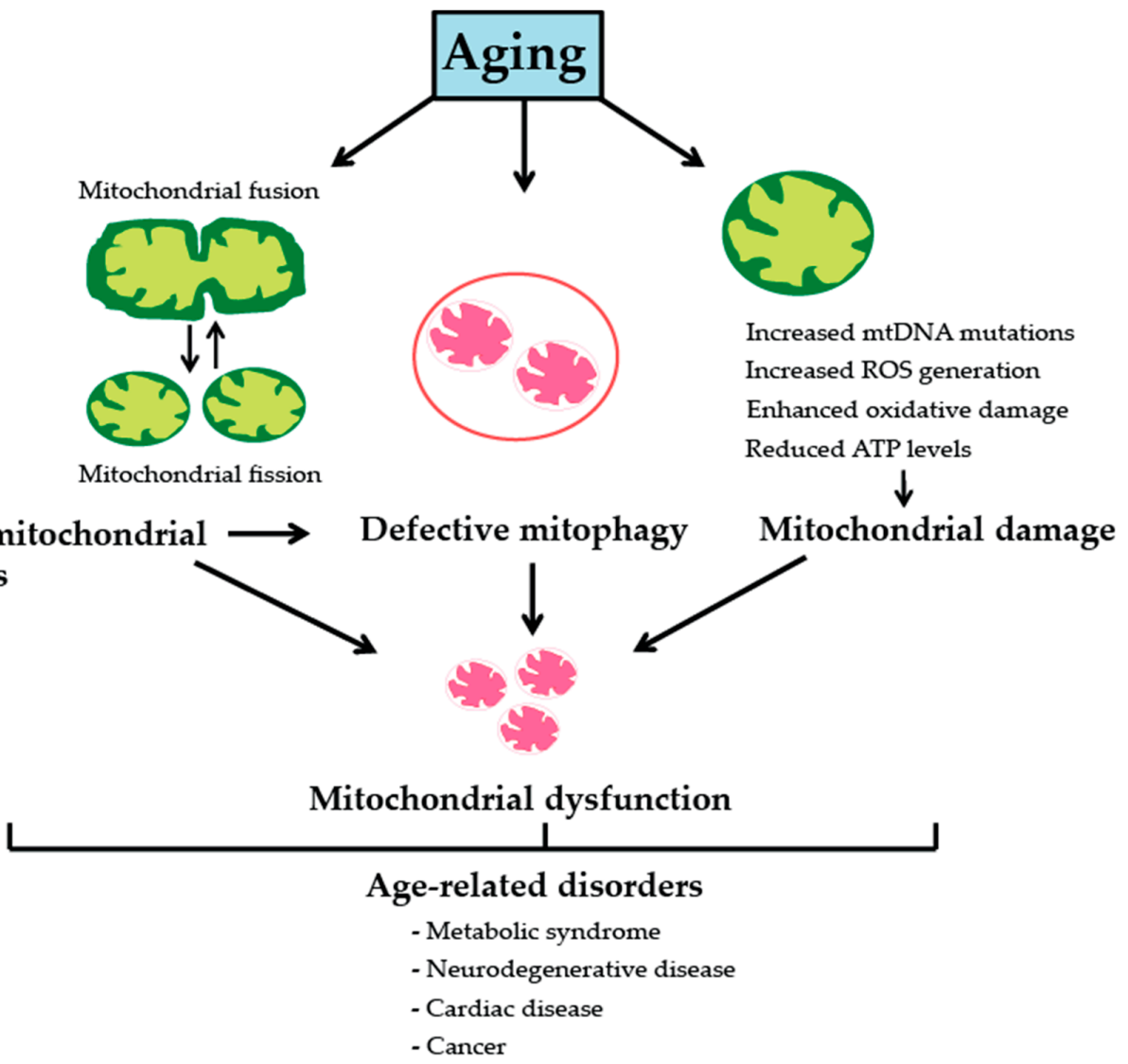

Figure 1. Mitochondrial dysfunction during aging and age-related disorders. Aging is associated with progressive mitochondrial dysfunction that occurs due to accumulation of mitochondrial DNA (mtDNA) mutations and increased reactive oxygen species (ROS) production that causes oxidative damage to cellular macromolecules, thereby leading to reduced respiratory chain activity and adenosine triphosphate (ATP) generation. Mitochondrial fission and fusion play a vital role in the regulation of mitochondrial function, metabolism and quality control. Altered mitochondrial dynamics with chronological age can inhibit mitophagy leading to accumulation of damaged or dysfunctional mitochondria in cells. Moreover, decline in mitophagy with increasing age prevents clearance of dysfunctional mitochondria leading to further mitochondrial damage accrual and deterioration of cellular function. Genetic mutations or functional declines in mitochondrial dynamics and quality control are thus linked to pathogenesis of numerous age-related disorders including metabolic syndrome, neurodegenerative and cardiovascular diseases as well as cancer.

\subsection{Reactive Oxgygen Species and Oxidative Stress}

Reactive oxygen species are an important byproduct of oxidative metabolism that comprises of superoxide anions $\left(\mathrm{O}_{2}{ }^{\bullet-}\right)$, hydrogen peroxide $\left(\mathrm{H}_{2} \mathrm{O}_{2}\right)$ and hydroxyl $\left({ }^{\bullet} \mathrm{OH}\right)$ radicals. Single electron reduction of molecular $\mathrm{O}_{2}$ generates $\mathrm{O}_{2}{ }^{\bullet-}$ anions which are rapidly converted by superoxide dismutases (SODs) to produce $\mathrm{H}_{2} \mathrm{O}_{2}$, whereas in the presence of reduced transition metals the $\mathrm{H}_{2} \mathrm{O}_{2}$ is converted to highly reactive ${ }^{\bullet} \mathrm{OH}$ radicals by Fenton reaction [51,52]. ROS spontaneously oxidizes nucleic acids, lipids and proteins causing macromolecular damage [53-55]. The free radical theory of aging postulates that progressive mitochondrial dysfunction with chronological age increases ROS production, which in turn causes oxidative damage to cellular macromolecules, thereby initiating a 'vicious cycle' of ROS generation and molecular damage accumulation [25,26]. An imbalance between excessive ROS production and limited cellular anti-oxidant defense capability leads to oxidative stress [51]. A role for ROS in aging has been reinforced by various studies demonstrating that ROS levels and oxidative damage increase with chronological age, ROS production increases with inhibition 
of mitochondrial function, mitochondrial dysfunction increases with age and several age-related pathologies are associated with increased ROS production and oxidative stress (Figure 1) [53,55-59]. Although these findings suggest a tight link between ROS generation and oxidative damage during aging, whether increased ROS production is a cause or consequence of aging remained controversial. In the past decade, a number of studies have found that moderate increase in ROS levels in response to stress serves as a survival signal that extends lifespan, and that increased oxidative stress does not reduce lifespan in multiple model organisms. For example, increased ROS production was shown to extend lifespan in both yeast and Caenorhabditis elegans $[60,61]$. Reduced superoxide dismutase 2 (Sod2) activity in heterozygous Sod $2^{+/-}$mutant mice triggered enhanced oxidative DNA damage but did not accelerate aging [62]. Mice with a combined deficiency of Sod2 and glutathione peroxidase-1 (Gpx-1) antioxidant enzymes also showed increased oxidative damage but no lifespan shortening [63]. Interestingly, mtDNA mutations that do not cause oxidative stress accelerate aging in mice [42,43,64-66] and mtDNA is not more susceptible to oxidative damage than nuclear DNA due to its closer proximity to the site of mitochondrial ROS generation [67]. Together, these findings implicate that increased ROS generation or oxidative stress is not the primary or initial cause, but rather a consequence of aging which thus prompts a re-evaluation/reconsideration of the role of free radical theory in aging. Future studies are needed to determine whether enhanced ROS production and oxidative stress are underlying causes of mitochondrial dysfunction in various age-related pathologies or whether bioenergetic deficiency is the primary causal factor.

\subsection{Mitochondrial Dynamics}

Mitochondria are highly dynamic structures as they continuously undergo fission and fusion processes (Figure 1) that shape their morphology and regulate mitochondrial size, number and function [68]. Mitochondrial dynamics is essential for mitochondrial viability and response to changes in cellular bioenergetic status [69]. Mitochondrial fission is vital for mitotic segregation of mitochondria to daughter cells, distribution of mitochondria to subcellular locations, and mitophagy [70-72]. Unopposed fission leads to mitochondrial fragmentation, loss of OXPHOS function, mtDNA depletion and ROS production, which are associated with metabolic dysfunction or disease [73]. Mitochondrial fusion is essential for maintaining mitochondrial membrane potential, ATP production and maximal respiratory capacity. Unopposed fusion generates a network of hyperfused mitochondria associated with increased ATP production, reduced ROS generation and which exhibit an ability to counteract metabolic insults, protect against autophagy as well as apoptosis [73]. Changes in metabolic demand and nutrient availability regulates the rate of fission and fusion causing mitochondria to become either fragmented or hypertubular $[74,75]$. In mammals, mitochondrial fission is mediated by the action of dynamin-related protein (DRP1) which is recruited to mitochondria by multiple receptors (e.g., fission 1 protein (FIS1), mitochondrial fission factor (MFF), mitochondrial dynamics proteins of $49 \mathrm{kDa}$ (MID49) and $51 \mathrm{kDa}$ (MID51) respectively) whereas mitochondrial fusion is a two-step process that involves the action of mitofusins for outer membrane (i.e., MFN1 and MFN2) and inner membrane (i.e., optic atrophy 1 (OPA1)) fusion [68]. Ablation of mitochondrial fission and fusion proteins has been shown to cause embryonic lethality in mice [76-78].

In the past decade, several studies have shown that mitochondrial dynamics plays a crucial role in the regulation of mitochondrial function and metabolism, mtDNA stability, calcium homeostasis, autophagy, mitophagy as well as apoptosis [79-87]. Altered mitochondrial dynamics is therefore strongly linked to aging and various age-related diseases (Figure 1) [87,88]. For example, it has been documented that aging is characterized by a progressive decline in Mfn2 expression in skeletal muscle, which promotes mitochondrial dysfunction and underlies the age-related disturbances in metabolic homeostasis as well as sarcopenia [87]. Reduced expression of Mfn1 and/or Mfn2 in skeletal muscle has been linked to obesity and type 2 diabetes mellitus in both rodents and humans $[81,89,90]$. Furthermore, the liver-specific ablation of $M f n 2$ in mice was shown to cause glucose intolerance and enhanced gluconeogenesis resulting in impaired insulin signaling and glucose homeostasis 
in vivo [81]. The pro-opiomelanocortin (POMC) neuronal-specific Mfn2 ablation in mice caused hyperphagia, reduced energy expenditure, endoplasmic reticulum stress-induced leptin resistance and obesity, indicating that Mfn2 plays a vital role in maintaining systemic energy balance [91]. Interestingly, the agouti-related protein (AGRP) neuronal-specific $M f n 1$ or $M f n 2$ deletion in mice exhibited altered mitochondrial size and density in AGRP neurons but gained less weight in response to high-fat diet due to reduced fat mass [92]. The liver-specific $M f n 1$ deletion in mice displayed a highly fragmented mitochondrial network coupled to enhanced respiratory capacity and these mice were also protected against the high-fat diet-induced insulin resistance [85]. Recently, using brown adipose tissue-specific $M f n 2$ knockout mice it was demonstrated that Mfn2 is crucial for thermogenesis, and when fed a high-fat diet, these mice are protected against insulin resistance, hepatic steatosis and obesity $[93,94]$. Together, these findings suggest variable cell and tissue-specific effects of mitofusins in the regulation of whole-body energy metabolism that warrant further investigation. In contrast to mitofusins, increased expression of mitochondrial fission proteins in mouse skeletal muscle have been linked to obesity [90]. Thus, genetic or pharmacological inhibition of Drp1 improved muscle insulin sensitivity and insulin signaling in obese mice, as well as conferred protection against high-fat diet-induced obesity in liver-specific Drp1 deleted mice [95,96].

Alterations in mitochondrial fission and fusion machinery have also been linked to several other age-related disorders including cardiac and neurodegenerative diseases, muscle atrophy and sarcopenia. For instance, reduced Mfn1 and/or Mfn2 expression were reported to induce vascular proliferative disorders i.e., atherosclerosis and restenosis, cardiac hypertrophy, cardiomyopathy as well as cardiac failure in rodents [97-100]. Interestingly, heart-specific deletion of both $M f n 1$ and $M f n 2$ also conferred protection against myocardial infarction caused by acute ischemia/reperfusion injury suggesting distinct roles of mitofusins in response to acute or chronic cardiac insults [101]. Decreased Opa1 levels have been associated with cardiomyopathy and heart failure in mice [80,102], whereas enhancing Opa1 levels protected mice hearts and brain from ischemic damage [84]. Moreover, inhibition of Drp1-mediated mitochondrial fragmentation showed protection against long-term cardiac dysfunction [103] as well as neurodegeneration associated with Huntington's disease in rodents [104]. Genetic mutations or alterations in mitochondrial fusion and fission are also linked to neuropathies [105,106], abnormal brain development, microcephaly, optic atrophy and hypoplasia [107], degeneration of cerebellum and dopaminergic neurons $[108,109]$, as well as defective neurodevelopment, plasticity and function in various neurodegenerative disorders e.g., Alzheimer's disease, Parkinson's disease and Huntington's disease $[82,110,111]$. Furthermore, reduced expression of mitochondrial fission and fusion proteins has been observed in muscle from rodents and humans during aging [87,112-114]. The skeletal muscle-specific knockdown of fusion proteins (i.e., Mfn1 and Mfn2) and overexpression of fission proteins (Drp1 and Fis1) was shown to induce muscle atrophy in mice, whereas inhibition of mitochondrial fission conferred protection against muscle atrophy in mice $[79,115,116]$. Together, these studies suggest that dysregulation of mitochondrial dynamics could contribute to aging and age-related pathologies. However, there are several outstanding questions that yet remain to be addressed regarding the link between mitochondrial dynamics and aging. For example, which factors cause altered expression of mitochondrial fission and fusion proteins during aging, and whether these factors are genetic or affected by environmental stimuli? Is altered mitochondrial dynamics a major cause of mitochondrial dysfunction in aged cells or tissues? Which signaling pathways regulate mitochondrial dynamics and how does their modulation affect aging-related phenotypes in model organisms? What are the physiological and metabolic consequences of perturbed mitochondrial dynamics and do different tissues respond similarly or differently to these perturbations? Whether proteins involved in mitochondrial dynamics could serve as promising candidates for promoting healthy aging and/or alleviating various age-related pathologies? Future experimental studies that are designed to address these questions would help to better understand the role of mitochondrial dynamics in aging and age-related pathologies. 


\subsection{Mitophagy and Mitochondrial Biogenesis}

Autophagy is a process by which intracellular components are delivered to lysosomes for degradation and recycling [117], whereas mitophagy is a specialized form of autophagy that involves selective degradation and removal of superfluous and damaged or dysfunctional mitochondria (Figure 1) [118]. Mitophagy is highly conserved among eukaryotes and has been extensively studied in yeast, Drosophila, C. elegans and mammalian cells [20,119,120]. Mammalian cells harbor multiple mitophagy pathways that can compensate for the loss of others. One of the most characterized mitophagy pathways is phosphatase and tensin homolog (PTEN)-induced putative kinase 1 (PINK1)/Parkin-dependent pathway although mitophagy can also occur in a Parkin-independent manner [121-126]. Interestingly, the rates of mitophagy are reportedly different between and within tissues [127], and in response to different intracellular and/or environmental cues, specific mitophagy pathways are activated to maintain mitochondrial function and cell homeostasis. The canonical PINK1/Parkin-dependent mitophagy pathway is activated in response to mitochondrial damage (e.g., loss of mitochondrial membrane potential or accumulation of misfolded proteins) that involves stabilization of PINK1 on the outer mitochondrial membrane where it phosphorylates ubiquitin [128]. The ubiquitin phosphorylation recruits cytosolic E3 ubiquitin-protein ligase-Parkin to mitochondrial outer membrane which polyubiquitinates mitochondrial proteins to facilitate their association with the autophagy receptors, thereby leading to the formation of autophagosome $[129,130]$. The autophagosome subsequently fuses with the lysosome to promote mitochondrial degradation [120,125]. Ubiquitination of mitochondrial proteins thus identifies or tags damaged mitochondria for Parkin-mediated mitophagy, a process shown to be inhibited by deubiquitination of Parkin substrates [131]. Alternatively, PINK1 can also recruit autophagy receptors directly to mitochondria in a Parkin-independent manner to mediate mitophagy [125]. Mutations in the human PINK1 and Parkin genes cause autosomal recessive forms of Parkinson's disease [132,133]. Germline deletion of Pink1 $1^{-/-}$in mice was reported to cause mitochondrial dysfunction in the striatum at 3-4 months of age that exacerbated with chronological age and enhanced sensitivity to oxidative stress, implicating that Pink1 is critical for mitochondrial function and protection against oxidative stress [134]. Parkin ${ }^{-/}$ablation in mice was also shown to cause brain mitochondrial dysfunction, enhanced oxidative damage and metabolic abnormalities; however, these mice did not show any signs of neurodegeneration $[135,136]$. Notably, when Parkin ${ }^{-/}$knockout mice $^{-}$ were crossed with the mtDNA mutator mice, the resulting mice progeny displayed an exacerbated response to mitochondrial dysfunction and degeneration of dopaminergic neurons in the substantia nigra region of the brain, suggesting that endogenous Parkin is crucial for protecting dopaminergic neurons against oxidative damage-induced cell death by enforcing mitochondrial quality control [137].

Mitochondrial fission and fusion play key roles in regulating mitophagy and quality control (Figure 1). For example, mitochondrial fission followed by selective fusion was shown to be required for the segregation of dysfunctional mitochondria and their subsequent removal by mitophagy in mammalian pancreatic $\beta$ cells [138]. Disruption of mitochondrial fission protein Drp1 was found to inhibit mitophagy in mouse cardiomyocytes [139,140]. Recently, it was demonstrated that mitochondrial fission promotes selective removal of mitochondria harboring misfolded protein aggregates [141]. Accumulating evidence also suggests that PINK1 and Parkin are required for mitophagy of damaged or dysfunctional mitochondria. For example, damaged mitochondria in human dopaminergic SH-SY5Y cells or Drosophila were shown to promote ubiquitination of mitofusins that targeted them for degradation via the PINK1/Parkin-dependent pathway [142,143]. Expression of a mutant ubiquitin (S65A) that could not be phosphorylated by PINK1 was shown to inhibit Parkin translocation to damaged mitochondria in HeLa cells [129]. Moreover, Mfn2 knockdown in mouse cardiac myocytes prevented Parkin translocation to depolarized mitochondria, thereby suppressing mitophagy, suggesting that Mfn2 is a mitochondrial receptor for Parkin and is critical for cardiac mitochondria quality control [100]. Despite recent research advances, the molecular mechanisms that connect mitochondrial dynamics and quality control systems remain obscure. Future studies should be directed at elucidating the mechanistic link between mitochondrial dynamics and mitophagy and determining whether it is deregulated during aging. 
Maintenance of mitochondrial function and cellular homeostasis not only requires selective elimination of defective mitochondria but also generation of newly synthesized mitochondria by stimulation of mitochondrial biogenesis program to maintain adequate mitochondrial mass and quality (Figure 2) [20]. Mitochondrial biogenesis is a tightly regulated process that involves coordinated transcriptional regulation of both nuclear and mitochondrial genomes to produce new mitochondria $[19,144]$. The transcription factors including nuclear respiratory factors i.e., NRF1 and NRF2, and transcriptional coactivators of the PPAR $\gamma$ coactivator- 1 family i.e., PGC1 $\alpha$, PGC1 $\beta$ and PGC1 related coactivator (PRC), are key components of the complex regulatory network that orchestrates mitochondrial biogenesis [144,145]. Both NRF1 and NRF2 regulate expression of several nuclear encoded mitochondrial proteins including mtDNA transcription factors A, B1 and B2 (i.e., TFAM, TFB1M, and TFB2M), as well as proteins involved in mitochondrial respiratory chain, import machinery and heme biosynthesis $[144,146]$. The peroxisome proliferator-activated receptor gamma coactivator $1 \alpha(\mathrm{PGC} 1 \alpha)$ is a master regulator of mitochondrial biogenesis as it co-activates expression of multiple transcription factors including NRF1, NRF2 and estrogen-related receptor $\alpha(E R R \alpha)[144,145]$.

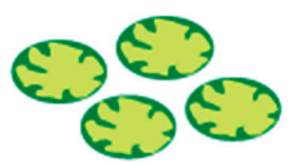

Mitochondrial biogenesis

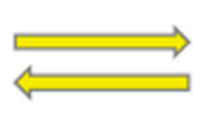

Mitophagy

Figure 2. Crosstalk between mitochondrial biogenesis and mitophagy. The crosstalk or coordination between the two opposing processes i.e., selective elimination of damaged or dysfunctional mitochondria by mitophagy and generation of newly synthesized mitochondria by mitochondrial biogenesis is pivotal for the maintenance of mitochondrial energy and cellular homeostasis in response to various physiological and environmental cues.

The crosstalk between mitochondrial biogenesis and turnover pathways is critical for cells to adjust their pool of functional mitochondria in response to physiological or metabolic demands, stress, and other intracellular or environmental cues (Figure 2). Coordination of these two opposing processes of mitochondrial biogenesis and degradation is achieved through multiple transcriptional and post-translational regulation mechanisms [147]. For instance, increased cyclic adenosine monophosphate (cAMP) levels cause protein kinase A (PKA)-dependent activation of cAMP response element binding protein (CREB) that upregulates PGC1 $\alpha$ expression and negatively regulates mitophagy via PKA-mediated phosphorylation and inhibition of LC3 [148,149]. In C. elegans, the transcription factor SKN-1 has been shown to regulate both mitophagy and mitochondrial biogenesis pathways [20]. This study demonstrated that impaired mitophagy in C. elegans compromises stress resistance and activates the mitochondrial retrograde signaling to induce SKN-1 expression, which in turn stimulates mitochondrial biogenesis and degradation by enhancing DCT-1 expression, suggesting a homeostatic feedback loop mechanism that integrates stress signal to coordinate induction of mitophagy and mitochondrial biogenesis pathways [20]. Additionally, besides stimulating mitochondrial biogenesis PGC1 $\alpha$ has also been shown to enhance mitophagy and autophagy by activating the expression of transcription factor EB (TFEB)-a master regulator of lysosomal biogenesis and autophagy [150], and TFEB in turn further stimulates PGC1 $\alpha$ expression, thereby generating a positive feedback loop mechanism to establish a balance between mitochondrial biogenesis and turnover [151]. Interestingly, a putative nutrient-sensing regulator (GCN5L1) was shown to negatively regulate both mitochondrial biogenesis and turnover pathways by inhibiting PGC1 $\alpha$ and TFEB expression, respectively, in mouse embryonic fibroblasts [152]. Furthermore, in response to cellular stress adenosine monophosphate (AMP)-activated kinase (AMPK) has been shown to induce mitophagy via mammalian 
target of rapamycin (mTOR) inhibition and ULK1 activation [153,154], whereas AMPK-mediated SIRT1 phosphorylation activates PGC1 $\alpha$, which stimulates mitochondrial biogenesis [155]. Finally, the mitogen-activated protein kinase/extracellular-signal-regulated kinase (MAPK/ERK) pathway activation has also been shown to stimulate mitochondrial biogenesis by enhancing PGC1 $\alpha$ expression as well as induce mitophagy in response to starvation or hypoxia-mediated cellular stress in mammalian cells $[156,157]$. Thus, coordination between mitophagy and mitochondrial biogenesis is pivotal in maintaining healthy mitochondrial population in eukaryotic cells in response to various environmental and intracellular cues. Deregulation of the mechanisms that coordinate mitochondrial biogenesis and turnover could lead to loss of energy and cellular homeostasis resulting in pathological conditions.

Decline in both mitophagy and autophagy pathways are associated with aging and various age-related pathologies including neurodegenerative, cardiac and immune system disorders, hepatic dysfunction, kidney failure as well as cancer [10,158-161]. For instance, age-dependent decline in mitophagy in C. elegans was shown to prevent clearance of dysfunctional mitochondria and mitochondrial biogenesis resulting in accrual of mitochondrial damage accompanied with deterioration of cellular function [20,21]. Defective mitophagy has been implicated in Parkinson's disease [16], and high levels of mtDNA deletions have been reported in the substantia nigra neurons from aged humans and patients with Parkinson's disease [40,162]. Enhanced mitophagy accompanied by Parkin depletion with disease progression was reported in the Alzheimer's disease patient brains, suggesting that an inadequate ability to eliminate dysfunctional mitochondria over time may lead to accrual of damaged mitochondria in neurons [163]. It has also been demonstrated that mutant huntingtin transcriptionally represses PGC1 $\alpha$ in mice, thereby inhibiting mitochondrial biogenesis [164] and impairs mitophagy in Drosophila neurons by reducing the targeting of damaged mitochondria to autophagosomes [165]. The overexpression of PINK1 alleviated defective mitophagy and ameliorated neuronal integrity, ATP levels as well as adult fly survival, suggesting that PINK confers neuroprotection against mutant huntingtin in flies [165]. Interestingly, the inhibition of mitochondrial deubiquitinase USP30 - an enzyme that antagonizes PINK1-Parkin-mediated mitophagy was also shown to promote mitochondrial clearance and quality control in fly neurons as well as improve mitochondrial integrity in PINK1- or Parkin-deficient flies [166]. Autophagy inhibition in mouse muscle was shown to impair neuromuscular synaptic function, muscle strength and significantly shorten the lifespan of mice [167]. Interestingly, the skeletal muscle from old mtDNA mutator mice exhibited increased mitochondrial fission and autophagy levels compared to the age-matched wild-type mice, indicating that higher autophagy in aged muscle of mtDNA mutator mice may be the cause of their sarcopenic phenotype [168]. Age-dependent decline in mitophagy/autophagy affects cardiac physiology and alterations in mitophagy/autophagy have been implicated in various heart diseases including cardiac hypertrophy, cardiomyopathy and heart failure. For example, cardiac specific loss of autophagy-related 5 (Atg5) in mice was shown to cause cardiomyopathy and cardiac hypertrophy associated with contractile dysfunction, disorganized sarcomeres, and accrual of dysfunctional mitochondria [169]. The PINK1-Parkin mitophagy pathway was also reported to be indispensable for normal heart function as Pink $1^{-/-}$deficient mice displayed cardiac hypertrophy, increased oxidative stress, mitochondrial dysfunction, higher fibrosis and cardiomyocyte apoptosis [170], whereas Parkin deficient mice exhibited increased sensitivity to myocardial infarction, reduced survival, and impaired mitophagy associated with accumulation of swollen dysfunctional mitochondria [171]. Moreover, Parkin deficiency with age was shown to cause accumulation of aberrant mitochondria in mouse myocytes [172]. Furthermore, impaired mitochondrial biogenesis is also linked to myocardial hypertrophy and ischemic heart failure in humans [173]. Thus, a proper balance between mitochondrial biogenesis and clearance is essential for cardiac homeostasis. Further research is needed to identify and validate novel pharmacological targets that restore coordination or balance between mitochondrial biogenesis and turnover pathways, which might be beneficial for aging retardation and/or combating various age-related pathologies.

As discussed above, mitochondrial quality control system ensures mitochondrial integrity, function and maintenance of a healthy mitochondrial population by limiting mitochondrial damage. Failure of 
mitochondrial quality control measures to remove damaged or dysfunctional mitochondria impairs protein homeostasis (or proteostasis), leading to the activation of apoptotic pathways $[23,174,175]$. Intriguingly, mitochondrial dynamics protein machinery has been linked to the regulation of apoptosis. For example, during apoptosis Drp1 translocates from the cytosol to mitochondria and promotes mitochondrial network fragmentation, whereas dominant negative Drp1 mutant expression prevents mitochondrial fragmentation, cytochrome $c$ release and apoptosis [176]. Other mitochondrial fission and fusion mediators have also been shown to regulate apoptosis including FIS1, OPA1, MFF1, MFN1 and MFN2 [177-179]. Interestingly, there is also a significant crosstalk between autophagy and apoptosis suggesting that these physiologically distinct processes share common targets and/or pathways [180]. The mitochondrial proteostasis system acts to ensure that proteins are maintained in their native folded state, while unfolded, misfolded or unassembled proteins are targeted for degradation by various proteases (e.g., AAA, Clp and Lon proteases) [23,181]. Aging and certain age-related diseases have been linked to proteostasis deficiency $[2,182,183]$. For instance, the activity of mitochondrial matrix Lon protease (LonP) which largely degrades oxidized proteins was found to be reduced with age in mice [184]. Furthermore, loss of proteostasis could result in accrual of unfolded, misfolded or aggregated proteins, leading to the development of age-related neurodegenerative disorders (e.g., Alzheimer's disease, Parkinson's disease, Huntington's disease) and cataracts [182]. The mitochondrial proteostasis and programmed cell death activation pathways during aging will not be discussed in depth here (see recent reviews that have covered these topics in detail [2,181-183,185-190]).

\subsection{Mitochondria-Mediated Longevity Pathways}

Mitochondria communicate changes in their functional and metabolic state to the nucleus through activation of a retrograde signaling pathway in response to various intracellular and environmental cues as well as during aging. Mitochondrial retrograde signaling pathway is thus an adaptive response that elicits coordinate expression of a broad array of nuclear genes in an attempt to restore mitochondrial energy and cellular homeostasis that promotes cell survival [191]. Studies from multiple model organisms indicated that loss in mitochondrial membrane potential, increased ROS generation and mitochondrial metabolites (e.g., ATP, nicotinamide adenine dinucleotide $\left(\mathrm{NAD}^{+}\right)$, acetyl coenzyme A (acetyl-CoA)) could serve as signal transducers to activate the mitochondrial-nuclear retrograde response [192,193]. Notably, the retrograde signaling pathway in yeast was initially shown to extend the cellular replicative lifespan [194]. Subsequently, many studies reported that mild respiratory chain impairment leading to low levels of ROS increase induces an adaptive or hormetic response which enhances cellular stress resistance and systemic defense-concept of 'mitohormesis' [195-197]. Mitohormesis has been shown to extend lifespan and promote health in multiple model organisms [195-197]. Mitochondrial stress that occurs due to accumulation of unfolded, misfolded or unassembled proteins elicits retrograde signaling that induces a distinct nuclear transcriptional response resulting in the induction of mitochondria-specific protein chaperones such as heat shock protein (HSP) factors. This retrograde signaling pathway is the mitochondrial unfolded protein response (UPR ${ }^{\mathrm{mt}}$ ) pathway, which is an adaptive response to the mitochondrial proteotoxic stress. The UPR ${ }^{\mathrm{mt}}$ pathway was elegantly described in C. elegans and has also been shown to extend lifespan in diverse model organisms including yeast, worms, flies and mice [191,198]. However, the precise mechanisms by which UPR ${ }^{\mathrm{mt}}$ pathway promotes longevity remain poorly understood. Moreover, the molecular components including sensors and signal transduction effectors as well as the potential mechanisms that regulate UPR ${ }^{\mathrm{mt}}$ pathway in mammals are yet to be completely uncovered. Interestingly, the mitochondrial stress response can also be elicited in distal tissues/organs that are not affected by the initial stress event through soluble factors or 'mitokines' in a non-cell-autonomous manner as demonstrated in C. elegans [199]. Multiple studies have recently identified new mitokines that are produced and secreted in response to mitochondrial stress i.e., the fibroblast growth factor 21 (FGF 21) and growth differentiation factor 15 (GDF15) [200,201]. These mitokines act on different tissues and organs to exert their systemic beneficial effects such as improved glucose tolerance, resistance to 
diet-induced obesity and weight loss [200]. The retrograde signaling pathway interacts with various other signaling pathways including the energy or nutrient sensing pathways such as AMPK, mTOR and insulin/insulin-like growth factor signaling (IIS) and is also linked to mitophagy and autophagy.

Emerging evidence suggests that enhanced mitophagy and autophagy pathways promote healthy aging as well as delay the onset and progression of various age-related pathologies [202]. For instance, enhanced mitophagy mediated by ubiquitous or neuron-specific overexpression of Parkin in Drosophila melanogaster significantly reduced age-associated proteotoxicity and extended the organismal lifespan [203]. Moreover, a natural compound, urolithin A found in pomegranates was recently shown to extend lifespan in C. elegans as well as enhance muscle function in rodents by inducing mitophagy [204]. Other natural compounds that exert beneficial effects on cellular energy metabolism and organismal health and lifespan include $\mathrm{NAD}^{+}$, resveratrol and spermidine [3,8,205-207]. Besides natural compounds, interventions such as dietary restriction, physical exercise and certain pharmacological drugs are known to retard aging and attenuate age-associated functional decline, thus promoting health and extending lifespan in diverse model organisms [3,208-210]. Beneficial effects of caloric restriction (CR) in aging retardation have been observed in yeast, flies, worms, mice as well as non-human primates, and recent studies suggest that autophagy is required for lifespan extension by CR in multiple model organisms [3,211-213]. Interestingly, the health benefits of physical exercise partially overlap with CR in terms of improving cellular metabolism, increasing $\mathrm{NAD}^{+}$availability that activates sirtuins, stimulating PGC1 $\alpha$ expression, and facilitating mitochondrial quality control [214-216]. Finally, pharmacological drugs such as rapamycin (mTOR inhibitor) and metformin (AMPK activator) also extend lifespan in model organisms and confer protection against several age-related pathologies $[217,218]$. Notably, the longevity mediating mitochondrial signaling pathways are highly interconnected and/or cross-regulated, resulting in a complex network that modulates common targets, which could be difficult to separate $[219,220]$. For instance, CR has been shown to ameliorate oxidative stress and extend organismal lifespan by modulating AMPK, mTOR, IIS and sirtuins signaling pathways [221]. Autophagy, which is required for lifespan extension effects mediated by CR, is also regulated by AMPK, MTOR, SIRT1 and FOXO signaling pathways [222-224]. Modulation of AMPK and mTOR signaling pathways could thus combine the simultaneous induction of mitochondrial biogenesis and autophagy/mitophagy to retard aging, promote longevity and protect against various age-related pathologies. Future studies are required to uncover the molecular connections and mechanisms that underlie the cross-regulation and interdependence of multiple signaling pathways during aging.

\section{Conclusions and Perspective}

Mitochondria are central to the regulation of energy metabolism and cellular homeostasis due to their principal role in bioenergetics, ROS production, ion homeostasis, apoptosis and signal transduction. These organelles are highly dynamic and can reprogram metabolism in response to various environmental and intracellular cues. Mitochondrial functional decline and accrual of damaged mitochondria in various tissues is associated with aging. However, the functional relevance of somatic mtDNA mutations in the aging process requires further clarification as they do not appear to be the main cause of aging. The relationship between ROS and aging is far more complex than it was originally perceived, and increased ROS or oxidative stress is also not the primary trigger of aging. In fact, moderate increase in ROS levels in response to caloric restriction, physical exercise or mild mitochondrial dysfunction promotes health and longevity in multiple model organisms-concept of mitohormesis [225]. Additional studies are however required to test whether similar to animal models mitohormesis also works in humans, and whether there is a precise threshold for mitochondrial impairment that could distinguish a hormetic response from pathological state. Maintenance of proteostasis is essential for healthy aging and could aid in the prevention of age-related disorders caused by protein misfolding. In fact, pharmacological drugs targeting multiple components of the proteostasis machinery are being tested in clinical trials [226]. 
Perturbations in mitochondrial function, biogenesis and dynamics impair cellular homeostasis and trigger mitochondrial quality control mechanisms. Altered mitochondrial dynamics and quality control promote accumulation of damaged mitochondria that contributes to aging and several age-related pathologies. Thus, strategies that effectively improve or rescue the defect in mitochondrial dynamics and quality control may be beneficial in combating aging and age-associated diseases. Towards this goal, development of small molecules that can therapeutically augment mitochondrial biogenesis, and pharmacological induction of mitophagy through use of mitophagy-activating compounds or $\mathrm{NAD}^{+}$supplementation might be beneficial for patients with age-related disorders and to combat aging. Additionally, agents that modulate the activity of PINK1, Parkin and USP30 could also promote mitophagy and prove beneficial in alleviating age-associated pathologies. In the upcoming years, further studies are needed to develop and test the potential effects of mitophagy modulators on cellular energy metabolism as well as organismal health and lifespan. Notably, mitophagy stimulation could be both beneficial or detrimental for tissue and organismal homeostasis based on the specific cellular bioenergetics requirement under healthy and diseased states. Therefore, effective new therapeutic strategies should involve coordinate induction of both mitophagy and mitochondrial biogenesis in order to maintain healthy mitochondrial population in cells. Finally, interventional studies will be necessary to test how mitophagy and mitochondrial biogenesis-inducing compounds impact human physiology and test their potential therapeutic efficacy for future clinical applications.

Acknowledgments: This work was supported by Virginia Tech open access subvention fund.

Conflicts of Interest: The author declares no conflict of interest.

\section{References}

1. Kennedy, B.K.; Berger, S.L.; Brunet, A.; Campisi, J.; Cuervo, A.M.; Epel, E.S.; Franceschi, C.; Lithgow, G.J.; Morimoto, R.I.; Pessin, J.E.; et al. Geroscience: Linking aging to chronic disease. Cell 2014, 159, 709-713. [CrossRef] [PubMed]

2. Lopez-Otin, C.; Blasco, M.A.; Partridge, L.; Serrano, M.; Kroemer, G. The hallmarks of aging. Cell 2013, 153, 1194-1217. [CrossRef] [PubMed]

3. Lopez-Otin, C.; Galluzzi, L.; Freije, J.M.P.; Madeo, F.; Kroemer, G. Metabolic control of longevity. Cell 2016, 166, 802-821. [CrossRef] [PubMed]

4. Nicholls, D.G. Mitochondria and calcium signaling. Cell Calcium 2005, 38, 311-317. [CrossRef] [PubMed]

5. Liu, Z.; Butow, R.A. Mitochondrial retrograde signaling. Annu. Rev. Genet. 2006, 40, 159-185. [CrossRef] [PubMed]

6. Nilsson, R.; Schultz, I.J.; Pierce, E.L.; Soltis, K.A.; Naranuntarat, A.; Ward, D.M.; Baughman, J.M.; Paradkar, P.N.; Kingsley, P.D.; Culotta, V.C.; et al. Discovery of genes essential for heme biosynthesis through large-scale gene expression analysis. Cell Metab. 2009, 10, 119-130. [CrossRef] [PubMed]

7. Wallace, D.C.; Fan, W.; Procaccio, V. Mitochondrial energetics and therapeutics. Annu. Rev. Pathol. 2010, 5, 297-348. [CrossRef] [PubMed]

8. Srivastava, S. Emerging therapeutic roles for $\mathrm{NAD}^{+}$metabolism in mitochondrial and age-related disorders. Clin. Transl. Med. 2016, 5, 25. [CrossRef] [PubMed]

9. Butow, R.A.; Avadhani, N.G. Mitochondrial signaling: The retrograde response. Mol. Cell 2004, 14, 1-15. [CrossRef]

10. Sun, N.; Youle, R.J.; Finkel, T. The mitochondrial basis of aging. Mol. Cell 2016, 61, 654-666. [CrossRef] [PubMed]

11. Kauppila, T.E.S.; Kauppila, J.H.K.; Larsson, N.G. Mammalian mitochondria and aging: An update. Cell Metab. 2017, 25, 57-71. [CrossRef] [PubMed]

12. Petersen, K.F.; Befroy, D.; Dufour, S.; Dziura, J.; Ariyan, C.; Rothman, D.L.; DiPietro, L.; Cline, G.W.; Shulman, G.I. Mitochondrial dysfunction in the elderly: Possible role in insulin resistance. Science 2003, 300, 1140-1142. [CrossRef] [PubMed]

13. Lowell, B.B.; Shulman, G.I. Mitochondrial dysfunction and type 2 diabetes. Science 2005, 307, $384-387$. [CrossRef] [PubMed] 
14. Wallace, D.C. Mitochondria and cancer. Nat. Rev. Cancer 2012, 12, 685-698. [CrossRef] [PubMed]

15. Lane, R.K.; Hilsabeck, T.; Rea, S.L. The role of mitochondrial dysfunction in age-related diseases. Biochim. Biophys. Acta 2015, 1847, 1387-1400. [CrossRef] [PubMed]

16. Ryan, B.J.; Hoek, S.; Fon, E.A.; Wade-Martins, R. Mitochondrial dysfunction and mitophagy in Parkinson's: From familial to sporadic disease. Trends Biochem. Sci. 2015, 40, 200-210. [CrossRef] [PubMed]

17. Tocchi, A.; Quarles, E.K.; Basisty, N.; Gitari, L.; Rabinovitch, P.S. Mitochondrial dysfunction in cardiac aging. Biochim. Biophys. Acta 2015, 1847, 1424-1433. [CrossRef] [PubMed]

18. Li, Q.O.Y.; Soro-Arnaiz, I.; Aragones, J. Age-dependent obesity and mitochondrial dysfunction. Adipocyte 2017, 6, 161-166. [CrossRef] [PubMed]

19. Lopez-Lluch, G.; Irusta, P.M.; Navas, P.; de Cabo, R. Mitochondrial biogenesis and healthy aging. Exp. Gerontol. 2008, 43, 813-819. [CrossRef] [PubMed]

20. Palikaras, K.; Lionaki, E.; Tavernarakis, N. Coordination of mitophagy and mitochondrial biogenesis during ageing in C. Elegans. Nature 2015, 521, 525-528. [CrossRef] [PubMed]

21. Palikaras, K.; Lionaki, E.; Tavernarakis, N. Coupling mitogenesis and mitophagy for longevity. Autophagy 2015, 11, 1428-1430. [CrossRef] [PubMed]

22. D'Amico, D.; Sorrentino, V.; Auwerx, J. Cytosolic proteostasis networks of the mitochondrial stress response. Trends Biochem. Sci. 2017, 42, 712-725. [CrossRef] [PubMed]

23. Rose, G.; Santoro, A.; Salvioli, S. Mitochondria and mitochondria-induced signalling molecules as longevity determinants. Mech. Ageing Dev. 2017, 165, 115-128. [CrossRef] [PubMed]

24. DiMauro, S.; Schon, E.A. Mitochondrial respiratory-chain diseases. N. Engl. J. Med. 2003, 348, $2656-2668$. [CrossRef] [PubMed]

25. Harman, D. The biologic clock: The mitochondria? J. Am. Geriatr. Soc. 1972, 20, 145-147. [CrossRef] [PubMed]

26. Harman, D. Aging: A theory based on free radical and radiation chemistry. J. Gerontol. 1956, 11, $298-300$. [CrossRef] [PubMed]

27. Linnane, A.W.; Marzuki, S.; Ozawa, T.; Tanaka, M. Mitochondrial DNA mutations as an important contributor to ageing and degenerative diseases. Lancet 1989, 1, 642-645. [CrossRef]

28. Trounce, I.; Byrne, E.; Marzuki, S. Decline in skeletal muscle mitochondrial respiratory chain function: Possible factor in ageing. Lancet 1989, 1, 637-639. [CrossRef]

29. Muller-Hocker, J. Cytochrome c oxidase deficient fibres in the limb muscle and diaphragm of man without muscular disease: An age-related alteration. J. Neurol. Sci. 1990, 100, 14-21. [CrossRef]

30. Muller-Hocker, J. Cytochrome-c-oxidase deficient cardiomyocytes in the human heart-An age-related phenomenon. A histochemical ultracytochemical study. Am. J. Pathol. 1989, 134, 1167-1173. [PubMed]

31. Munscher, C.; Muller-Hocker, J.; Kadenbach, B. Human aging is associated with various point mutations in tRNA genes of mitochondrial DNA. Biol. Chem. Hoppe Seyler 1993, 374, 1099-1104. [CrossRef] [PubMed]

32. Cottrell, D.A.; Blakely, E.L.; Johnson, M.A.; Ince, P.G.; Borthwick, G.M.; Turnbull, D.M. Cytochrome c oxidase deficient cells accumulate in the hippocampus and choroid plexus with age. Neurobiol. Aging 2001, 22, 265-272. [CrossRef]

33. Cortopassi, G.A.; Arnheim, N. Detection of a specific mitochondrial DNA deletion in tissues of older humans. Nucleic Acids Res. 1990, 18, 6927-6933. [CrossRef] [PubMed]

34. Piko, L.; Hougham, A.J.; Bulpitt, K.J. Studies of sequence heterogeneity of mitochondrial DNA from rat and mouse tissues: Evidence for an increased frequency of deletions/additions with aging. Mech. Ageing Dev. 1988, 43, 279-293. [CrossRef]

35. Bua, E.; Johnson, J.; Herbst, A.; Delong, B.; McKenzie, D.; Salamat, S.; Aiken, J.M. Mitochondrial DNA-deletion mutations accumulate intracellularly to detrimental levels in aged human skeletal muscle fibers. Am. J. Hum. Genet. 2006, 79, 469-480. [CrossRef] [PubMed]

36. Wanagat, J.; Cao, Z.; Pathare, P.; Aiken, J.M. Mitochondrial DNA deletion mutations colocalize with segmental electron transport system abnormalities, muscle fiber atrophy, fiber splitting, and oxidative damage in sarcopenia. FASEB J. 2001, 15, 322-332. [CrossRef] [PubMed]

37. Soong, N.W.; Hinton, D.R.; Cortopassi, G.; Arnheim, N. Mosaicism for a specific somatic mitochondrial DNA mutation in adult human brain. Nat. Genet. 1992, 2, 318-323. [CrossRef] [PubMed] 
38. Dufour, E.; Terzioglu, M.; Sterky, F.H.; Sorensen, L.; Galter, D.; Olson, L.; Wilbertz, J.; Larsson, N.G. Age-associated mosaic respiratory chain deficiency causes trans-neuronal degeneration. Hum. Mol. Genet. 2008, 17, 1418-1426. [CrossRef] [PubMed]

39. Itoh, K.; Weis, S.; Mehraein, P.; Muller-Hocker, J. Cytochrome c oxidase defects of the human substantia nigra in normal aging. Neurobiol. Aging 1996, 17, 843-848. [CrossRef]

40. Kraytsberg, Y.; Kudryavtseva, E.; McKee, A.C.; Geula, C.; Kowall, N.W.; Khrapko, K. Mitochondrial DNA deletions are abundant and cause functional impairment in aged human substantia nigra neurons. Nat. Genet. 2006, 38, 518-520. [CrossRef] [PubMed]

41. Taylor, R.W.; Barron, M.J.; Borthwick, G.M.; Gospel, A.; Chinnery, P.F.; Samuels, D.C.; Taylor, G.A.; Plusa, S.M.; Needham, S.J.; Greaves, L.C.; et al. Mitochondrial DNA mutations in human colonic crypt stem cells. J. Clin. Investig. 2003, 112, 1351-1360. [CrossRef] [PubMed]

42. Trifunovic, A.; Wredenberg, A.; Falkenberg, M.; Spelbrink, J.N.; Rovio, A.T.; Bruder, C.E.; Bohlooly, Y.M.; Gidlof, S.; Oldfors, A.; Wibom, R.; et al. Premature ageing in mice expressing defective mitochondrial DNA polymerase. Nature 2004, 429, 417-423. [CrossRef] [PubMed]

43. Kujoth, G.C.; Hiona, A.; Pugh, T.D.; Someya, S.; Panzer, K.; Wohlgemuth, S.E.; Hofer, T.; Seo, A.Y.; Sullivan, R.; Jobling, W.A.; et al. Mitochondrial DNA mutations, oxidative stress, and apoptosis in mammalian aging. Science 2005, 309, 481-484. [CrossRef] [PubMed]

44. Khrapko, K.; Vijg, J. Mitochondrial DNA mutations and aging: A case closed? Nat. Genet. 2007, 39, 445-446. [CrossRef] [PubMed]

45. Khrapko, K.; Vijg, J. Mitochondrial DNA mutations and aging: Devils in the details? Trends Genet. 2009, 25, 91-98. [CrossRef] [PubMed]

46. Rossignol, R.; Faustin, B.; Rocher, C.; Malgat, M.; Mazat, J.P.; Letellier, T. Mitochondrial threshold effects. Biochem. J. 2003, 370, 751-762. [CrossRef] [PubMed]

47. Khrapko, K.; Kraytsberg, Y.; de Grey, A.D.; Vijg, J.; Schon, E.A. Does premature aging of the mtDNA mutator mouse prove that mtDNA mutations are involved in natural aging? Aging Cell 2006, 5, 279-282. [CrossRef] [PubMed]

48. Inoue, K.; Nakada, K.; Ogura, A.; Isobe, K.; Goto, Y.; Nonaka, I.; Hayashi, J.I. Generation of mice with mitochondrial dysfunction by introducing mouse mtDNA carrying a deletion into zygotes. Nat. Genet. 2000, 26, 176-181. [CrossRef] [PubMed]

49. Nakada, K.; Inoue, K.; Ono, T.; Isobe, K.; Ogura, A.; Goto, Y.I.; Nonaka, I.; Hayashi, J.I. Inter-mitochondrial complementation: Mitochondria-specific system preventing mice from expression of disease phenotypes by mutant mtDNA. Nat. Med. 2001, 7, 934-940. [CrossRef] [PubMed]

50. Vermulst, M.; Bielas, J.H.; Kujoth, G.C.; Ladiges, W.C.; Rabinovitch, P.S.; Prolla, T.A.; Loeb, L.A. Mitochondrial point mutations do not limit the natural lifespan of mice. Nat. Genet. 2007, 39, 540-543. [CrossRef] [PubMed]

51. Turrens, J.F. Mitochondrial formation of reactive oxygen species. J. Physiol. 2003, 552, 335-344. [CrossRef] [PubMed]

52. Brand, M.D. The sites and topology of mitochondrial superoxide production. Exp. Gerontol. 2010, 45, 466-472. [CrossRef] [PubMed]

53. Fraga, C.G.; Shigenaga, M.K.; Park, J.W.; Degan, P.; Ames, B.N. Oxidative damage to DNA during aging: 8-Hydroxy-2'-deoxyguanosine in rat organ DNA and urine. Proc. Natl. Acad. Sci. USA 1990, 87, 4533-4537. [CrossRef] [PubMed]

54. Niki, E. Lipid peroxidation: Physiological levels and dual biological effects. Free Radic. Biol. Med. 2009, 47, 469-484. [CrossRef] [PubMed]

55. Ugarte, N.; Petropoulos, I.; Friguet, B. Oxidized mitochondrial protein degradation and repair in aging and oxidative stress. Antioxid. Redox Signal. 2010, 13, 539-549. [CrossRef] [PubMed]

56. Sohal, R.S.; Sohal, B.H. Hydrogen peroxide release by mitochondria increases during aging. Mech. Ageing Dev. 1991, 57, 187-202. [CrossRef]

57. Asensi, M.; Sastre, J.; Pallardo, F.V.; Lloret, A.; Lehner, M.; Garcia-de-la Asuncion, J.; Vina, J. Ratio of reduced to oxidized glutathione as indicator of oxidative stress status and DNA damage. Methods Enzymol. 1999, 299, 267-276. [PubMed]

58. Balaban, R.S.; Nemoto, S.; Finkel, T. Mitochondria, oxidants, and aging. Cell 2005, 120, 483-495. [CrossRef] [PubMed] 
59. Cho, J.; Hur, J.H.; Walker, D.W. The role of mitochondria in Drosophila aging. Exp. Gerontol. 2011, 46, 331-334. [CrossRef] [PubMed]

60. Doonan, R.; McElwee, J.J.; Matthijssens, F.; Walker, G.A.; Houthoofd, K.; Back, P.; Matscheski, A.; Vanfleteren, J.R.; Gems, D. Against the oxidative damage theory of aging: Superoxide dismutases protect against oxidative stress but have little or no effect on life span in Caenorhabditis elegans. Genes Dev. 2008, 22, 3236-3241. [CrossRef] [PubMed]

61. Mesquita, A.; Weinberger, M.; Silva, A.; Sampaio-Marques, B.; Almeida, B.; Leao, C.; Costa, V.; Rodrigues, F.; Burhans, W.C.; Ludovico, P. Caloric restriction or catalase inactivation extends yeast chronological lifespan by inducing $\mathrm{H}_{2} \mathrm{O}_{2}$ and superoxide dismutase activity. Proc. Natl. Acad. Sci. USA 2010, 107, 15123-15128. [CrossRef] [PubMed]

62. Van Remmen, H.; Ikeno, Y.; Hamilton, M.; Pahlavani, M.; Wolf, N.; Thorpe, S.R.; Alderson, N.L.; Baynes, J.W.; Epstein, C.J.; Huang, T.T.; et al. Life-long reduction in MnSOD activity results in increased DNA damage and higher incidence of cancer but does not accelerate aging. Physiol. Genom. 2003, 16, 29-37. [CrossRef] [PubMed]

63. Zhang, Y.; Ikeno, Y.; Qi, W.; Chaudhuri, A.; Li, Y.; Bokov, A.; Thorpe, S.R.; Baynes, J.W.; Epstein, C.; Richardson, A.; et al. Mice deficient in both Mn superoxide dismutase and glutathione peroxidase-1 have increased oxidative damage and a greater incidence of pathology but no reduction in longevity. J. Gerontol. A 2009, 64, 1212-1220. [CrossRef] [PubMed]

64. Trifunovic, A.; Hansson, A.; Wredenberg, A.; Rovio, A.T.; Dufour, E.; Khvorostov, I.; Spelbrink, J.N.; Wibom, R.; Jacobs, H.T.; Larsson, N.G. Somatic mtDNA mutations cause aging phenotypes without affecting reactive oxygen species production. Proc. Natl. Acad. Sci. USA 2005, 102, 17993-17998. [CrossRef] [PubMed]

65. Edgar, D.; Shabalina, I.; Camara, Y.; Wredenberg, A.; Calvaruso, M.A.; Nijtmans, L.; Nedergaard, J.; Cannon, B.; Larsson, N.G.; Trifunovic, A. Random point mutations with major effects on protein-coding genes are the driving force behind premature aging in mtDNA mutator mice. Cell Metab. 2009, 10, 131-138. [CrossRef] [PubMed]

66. Hiona, A.; Sanz, A.; Kujoth, G.C.; Pamplona, R.; Seo, A.Y.; Hofer, T.; Someya, S.; Miyakawa, T.; Nakayama, C.; Samhan-Arias, A.K.; et al. Mitochondrial DNA mutations induce mitochondrial dysfunction, apoptosis and sarcopenia in skeletal muscle of mitochondrial DNA mutator mice. PLoS ONE 2010, 5, e11468. [CrossRef] [PubMed]

67. Lim, K.S.; Jeyaseelan, K.; Whiteman, M.; Jenner, A.; Halliwell, B. Oxidative damage in mitochondrial DNA is not extensive. Ann. N. Y. Acad. Sci. 2005, 1042, 210-220. [CrossRef] [PubMed]

68. Chan, D.C. Fusion and fission: Interlinked processes critical for mitochondrial health. Annu. Rev. Genet. 2012, 46, 265-287. [CrossRef] [PubMed]

69. Benard, G.; Bellance, N.; James, D.; Parrone, P.; Fernandez, H.; Letellier, T.; Rossignol, R. Mitochondrial bioenergetics and structural network organization. J. Cell Sci. 2007, 120, 838-848. [CrossRef] [PubMed]

70. Saxton, W.M.; Hollenbeck, P.J. The axonal transport of mitochondria. J. Cell Sci. 2012, 125, $2095-2104$. [CrossRef] [PubMed]

71. Otera, H.; Ishihara, N.; Mihara, K. New insights into the function and regulation of mitochondrial fission. Biochim. Biophys. Acta 2013, 1833, 1256-1268. [CrossRef] [PubMed]

72. Gomes, L.C.; Scorrano, L. Mitochondrial morphology in mitophagy and macroautophagy. Biochim. Biophys. Acta 2013, 1833, 205-212. [CrossRef] [PubMed]

73. Liesa, M.; Shirihai, O.S. Mitochondrial dynamics in the regulation of nutrient utilization and energy expenditure. Cell Metab. 2013, 17, 491-506. [CrossRef] [PubMed]

74. Rambold, A.S.; Kostelecky, B.; Elia, N.; Lippincott-Schwartz, J. Tubular network formation protects mitochondria from autophagosomal degradation during nutrient starvation. Proc. Natl. Acad. Sci. USA 2011, 108, 10190-10195. [CrossRef] [PubMed]

75. Wai, T.; Langer, T. Mitochondrial dynamics and metabolic regulation. Trends Endocrinol. Metab. 2016, 27, 105-117. [CrossRef] [PubMed]

76. Chen, H.; Detmer, S.A.; Ewald, A.J.; Griffin, E.E.; Fraser, S.E.; Chan, D.C. Mitofusins Mfn1 and Mfn2 coordinately regulate mitochondrial fusion and are essential for embryonic development. J. Cell Biol. 2003, 160, 189-200. [CrossRef] [PubMed] 
77. Davies, V.J.; Hollins, A.J.; Piechota, M.J.; Yip, W.; Davies, J.R.; White, K.E.; Nicols, P.P.; Boulton, M.E.; Votruba, M. Opa1 deficiency in a mouse model of autosomal dominant optic atrophy impairs mitochondrial morphology, optic nerve structure and visual function. Hum. Mol. Genet. 2007, 16, 1307-1318. [CrossRef] [PubMed]

78. Ishihara, N.; Nomura, M.; Jofuku, A.; Kato, H.; Suzuki, S.O.; Masuda, K.; Otera, H.; Nakanishi, Y.; Nonaka, I.; Goto, Y.; et al. Mitochondrial fission factor Drp1 is essential for embryonic development and synapse formation in mice. Nat. Cell Biol. 2009, 11, 958-966. [CrossRef] [PubMed]

79. Chen, H.; Vermulst, M.; Wang, Y.E.; Chomyn, A.; Prolla, T.A.; McCaffery, J.M.; Chan, D.C. Mitochondrial fusion is required for mtDNA stability in skeletal muscle and tolerance of mtDNA mutations. Cell 2010, 141, 280-289. [CrossRef] [PubMed]

80. Chen, L.; Liu, T.; Tran, A.; Lu, X.; Tomilov, A.A.; Davies, V.; Cortopassi, G.; Chiamvimonvat, N.; Bers, D.M.; Votruba, M.; et al. OPA1 mutation and late-onset cardiomyopathy: Mitochondrial dysfunction and mtDNA instability. J. Am. Heart Assoc. 2012, 1, e003012. [CrossRef] [PubMed]

81. Sebastian, D.; Hernandez-Alvarez, M.I.; Segales, J.; Sorianello, E.; Munoz, J.P.; Sala, D.; Waget, A.; Liesa, M.; Paz, J.C.; Gopalacharyulu, P.; et al. Mitofusin 2 (Mfn2) links mitochondrial and endoplasmic reticulum function with insulin signaling and is essential for normal glucose homeostasis. Proc. Natl. Acad. Sci. USA 2012, 109, 5523-5528. [CrossRef] [PubMed]

82. Burte, F.; Carelli, V.; Chinnery, P.F.; Yu-Wai-Man, P. Disturbed mitochondrial dynamics and neurodegenerative disorders. Nat. Rev. Neurol. 2015, 11, 11-24. [CrossRef] [PubMed]

83. Mourier, A.; Motori, E.; Brandt, T.; Lagouge, M.; Atanassov, I.; Galinier, A.; Rappl, G.; Brodesser, S.; Hultenby, K.; Dieterich, C.; et al. Mitofusin 2 is required to maintain mitochondrial coenzyme Q levels. J. Cell Biol. 2015, 208, 429-442. [CrossRef] [PubMed]

84. Varanita, T.; Soriano, M.E.; Romanello, V.; Zaglia, T.; Quintana-Cabrera, R.; Semenzato, M.; Menabo, R.; Costa, V.; Civiletto, G.; Pesce, P.; et al. The Opa1-dependent mitochondrial cristae remodeling pathway controls atrophic, apoptotic, and ischemic tissue damage. Cell Metab. 2015, 21, 834-844. [CrossRef] [PubMed]

85. Kulkarni, S.S.; Joffraud, M.; Boutant, M.; Ratajczak, J.; Gao, A.W.; Maclachlan, C.; Hernandez-Alvarez, M.I.; Raymond, F.; Metairon, S.; Descombes, P.; et al. Mfn1 deficiency in the liver protects against diet-induced insulin resistance and enhances the hypoglycemic effect of metformin. Diabetes 2016, 65, 3552-3560. [CrossRef] [PubMed]

86. Buck, M.D.; O’Sullivan, D.; Klein Geltink, R.I.; Curtis, J.D.; Chang, C.H.; Sanin, D.E.; Qiu, J.; Kretz, O.; Braas, D.; van der Windt, G.J.; et al. Mitochondrial dynamics controls $\mathrm{T}$ cell fate through metabolic programming. Cell 2016, 166, 63-76. [CrossRef] [PubMed]

87. Sebastian, D.; Sorianello, E.; Segales, J.; Irazoki, A.; Ruiz-Bonilla, V.; Sala, D.; Planet, E.; Berenguer-Llergo, A.; Munoz, J.P.; Sanchez-Feutrie, M.; et al. Mfn2 deficiency links age-related sarcopenia and impaired autophagy to activation of an adaptive mitophagy pathway. EMBO J. 2016, 35, 1677-1693. [CrossRef] [PubMed]

88. Sebastian, D.; Palacin, M.; Zorzano, A. Mitochondrial dynamics: Coupling mitochondrial fitness with healthy aging. Trends Mol. Med. 2017, 23, 201-215. [CrossRef] [PubMed]

89. Bach, D.; Pich, S.; Soriano, F.X.; Vega, N.; Baumgartner, B.; Oriola, J.; Daugaard, J.R.; Lloberas, J.; Camps, M.; Zierath, J.R.; et al. Mitofusin-2 determines mitochondrial network architecture and mitochondrial metabolism. A novel regulatory mechanism altered in obesity. J. Biol. Chem. 2003, 278, 17190-17197. [CrossRef] [PubMed]

90. Liu, R.; Jin, P.; Yu, L.; Wang, Y.; Han, L.; Shi, T.; Li, X. Impaired mitochondrial dynamics and bioenergetics in diabetic skeletal muscle. PLoS ONE 2014, 9, e92810. [CrossRef] [PubMed]

91. Schneeberger, M.; Dietrich, M.O.; Sebastian, D.; Imbernon, M.; Castano, C.; Garcia, A.; Esteban, Y.; Gonzalez-Franquesa, A.; Rodriguez, I.C.; Bortolozzi, A.; et al. Mitofusin 2 in POMC neurons connects ER stress with leptin resistance and energy imbalance. Cell 2013, 155, 172-187. [CrossRef] [PubMed]

92. Dietrich, M.O.; Liu, Z.W.; Horvath, T.L. Mitochondrial dynamics controlled by mitofusins regulate Agrp neuronal activity and diet-induced obesity. Cell 2013, 155, 188-199. [CrossRef] [PubMed]

93. Boutant, M.; Kulkarni, S.S.; Joffraud, M.; Ratajczak, J.; Valera-Alberni, M.; Combe, R.; Zorzano, A.; Canto, C. Mfn2 is critical for brown adipose tissue thermogenic function. EMBO J. 2017, 36, 1543-1558. [CrossRef] [PubMed] 
94. Mahdaviani, K.; Benador, I.Y.; Su, S.; Gharakhanian, R.A.; Stiles, L.; Trudeau, K.M.; Cardamone, M.; Enriquez-Zarralanga, V.; Ritou, E.; Aprahamian, T.; et al. Mfn2 deletion in brown adipose tissue protects from insulin resistance and impairs thermogenesis. EMBO Rep. 2017, 18, 1123-1138. [CrossRef] [PubMed]

95. Jheng, H.F.; Tsai, P.J.; Guo, S.M.; Kuo, L.H.; Chang, C.S.; Su, I.J.; Chang, C.R.; Tsai, Y.S. Mitochondrial fission contributes to mitochondrial dysfunction and insulin resistance in skeletal muscle. Mol. Cell. Biol. 2012, 32, 309-319. [CrossRef] [PubMed]

96. Wang, L.; Ishihara, T.; Ibayashi, Y.; Tatsushima, K.; Setoyama, D.; Hanada, Y.; Takeichi, Y.; Sakamoto, S.; Yokota, S.; Mihara, K.; et al. Disruption of mitochondrial fission in the liver protects mice from diet-induced obesity and metabolic deterioration. Diabetologia 2015, 58, 2371-2380. [CrossRef] [PubMed]

97. Chen, K.H.; Guo, X.; Ma, D.; Guo, Y.; Li, Q.; Yang, D.; Li, P.; Qiu, X.; Wen, S.; Xiao, R.P.; et al. Dysregulation of HSG triggers vascular proliferative disorders. Nat. Cell Biol. 2004, 6, 872-883. [CrossRef] [PubMed]

98. Fang, L.; Moore, X.L.; Gao, X.M.; Dart, A.M.; Lim, Y.L.; Du, X.J. Down-regulation of mitofusin-2 expression in cardiac hypertrophy in vitro and in vivo. Life Sci. 2007, 80, 2154-2160. [CrossRef] [PubMed]

99. Chen, Y.; Liu, Y.; Dorn, G.W., 2nd. Mitochondrial fusion is essential for organelle function and cardiac homeostasis. Circ. Res. 2011, 109, 1327-1331. [CrossRef] [PubMed]

100. Chen, Y.; Dorn, G.W., 2nd. Pink1-phosphorylated mitofusin 2 is a Parkin receptor for culling damaged mitochondria. Science 2013, 340, 471-475. [CrossRef] [PubMed]

101. Hall, A.R.; Burke, N.; Dongworth, R.K.; Kalkhoran, S.B.; Dyson, A.; Vicencio, J.M.; Dorn, G.W., II; Yellon, D.M.; Hausenloy, D.J. Hearts deficient in both Mfn1 and Mfn2 are protected against acute myocardial infarction. Cell Death Dis. 2016, 7, e2238. [CrossRef] [PubMed]

102. Wai, T.; Garcia-Prieto, J.; Baker, M.J.; Merkwirth, C.; Benit, P.; Rustin, P.; Ruperez, F.J.; Barbas, C.; Ibanez, B.; Langer, T. Imbalanced OPA1 processing and mitochondrial fragmentation cause heart failure in mice. Science 2015, 350, aad0116. [CrossRef] [PubMed]

103. Disatnik, M.H.; Ferreira, J.C.; Campos, J.C.; Gomes, K.S.; Dourado, P.M.; Qi, X.; Mochly-Rosen, D. Acute inhibition of excessive mitochondrial fission after myocardial infarction prevents long-term cardiac dysfunction. J. Am. Heart Assoc. 2013, 2, e000461. [CrossRef] [PubMed]

104. Guo, X.; Disatnik, M.H.; Monbureau, M.; Shamloo, M.; Mochly-Rosen, D.; Qi, X. Inhibition of mitochondrial fragmentation diminishes Huntington's disease-associated neurodegeneration. J. Clin. Investig. 2013, 123, 5371-5388. [CrossRef] [PubMed]

105. Delettre, C.; Lenaers, G.; Griffoin, J.M.; Gigarel, N.; Lorenzo, C.; Belenguer, P.; Pelloquin, L.; Grosgeorge, J.; Turc-Carel, C.; Perret, E.; et al. Nuclear gene OPA1, encoding a mitochondrial dynamin-related protein, is mutated in dominant optic atrophy. Nat. Genet. 2000, 26, 207-210. [CrossRef] [PubMed]

106. Zuchner, S.; Mersiyanova, I.V.; Muglia, M.; Bissar-Tadmouri, N.; Rochelle, J.; Dadali, E.L.; Zappia, M.; Nelis, E.; Patitucci, A.; Senderek, J.; et al. Mutations in the mitochondrial GTPase mitofusin 2 cause Charcot-Marie-Tooth neuropathy type 2A. Nat. Genet. 2004, 36, 449-451. [CrossRef] [PubMed]

107. Waterham, H.R.; Koster, J.; van Roermund, C.W.; Mooyer, P.A.; Wanders, R.J.; Leonard, J.V. A lethal defect of mitochondrial and peroxisomal fission. N. Engl. J. Med. 2007, 356, 1736-1741. [CrossRef] [PubMed]

108. Chen, H.; McCaffery, J.M.; Chan, D.C. Mitochondrial fusion protects against neurodegeneration in the cerebellum. Cell 2007, 130, 548-562. [CrossRef] [PubMed]

109. Pham, A.H.; Meng, S.; Chu, Q.N.; Chan, D.C. Loss of Mfn2 results in progressive, retrograde degeneration of dopaminergic neurons in the nigrostriatal circuit. Hum. Mol. Genet. 2012, 21, 4817-4826. [CrossRef] [PubMed]

110. Manczak, M.; Calkins, M.J.; Reddy, P.H. Impaired mitochondrial dynamics and abnormal interaction of amyloid beta with mitochondrial protein Drp1 in neurons from patients with Alzheimer's disease: Implications for neuronal damage. Hum. Mol. Genet. 2011, 20, 2495-2509. [CrossRef] [PubMed]

111. Shirendeb, U.P.; Calkins, M.J.; Manczak, M.; Anekonda, V.; Dufour, B.; McBride, J.L.; Mao, P.; Reddy, P.H. Mutant Huntingtin's interaction with mitochondrial protein Drp1 impairs mitochondrial biogenesis and causes defective axonal transport and synaptic degeneration in Huntington's disease. Hum. Mol. Genet. 2012, 21, 406-420. [CrossRef] [PubMed]

112. Crane, J.D.; Devries, M.C.; Safdar, A.; Hamadeh, M.J.; Tarnopolsky, M.A. The effect of aging on human skeletal muscle mitochondrial and intramyocellular lipid ultrastructure. J. Gerontol. A 2010, 65, 119-128. [CrossRef] [PubMed] 
113. Zhao, L.; Zou, X.; Feng, Z.; Luo, C.; Liu, J.; Li, H.; Chang, L.; Wang, H.; Li, Y.; Long, J.; et al. Evidence for association of mitochondrial metabolism alteration with lipid accumulation in aging rats. Exp. Gerontol. 2014, 56, 3-12. [CrossRef] [PubMed]

114. Marzetti, E.; Calvani, R.; Lorenzi, M.; Tanganelli, F.; Picca, A.; Bossola, M.; Menghi, A.; Bernabei, R.; Landi, F. Association between myocyte quality control signaling and sarcopenia in old hip-fractured patients: Results from the Sarcopenia in HIp FracTure (SHIFT) exploratory study. Exp. Gerontol. 2016, 80, 1-5. [CrossRef] [PubMed]

115. Romanello, V.; Guadagnin, E.; Gomes, L.; Roder, I.; Sandri, C.; Petersen, Y.; Milan, G.; Masiero, E.; Del Piccolo, P.; Foretz, M.; et al. Mitochondrial fission and remodelling contributes to muscle atrophy. EMBO J. 2010, 29, 1774-1785. [CrossRef] [PubMed]

116. Cannavino, J.; Brocca, L.; Sandri, M.; Grassi, B.; Bottinelli, R.; Pellegrino, M.A. The role of alterations in mitochondrial dynamics and PGC-1 $\alpha$ over-expression in fast muscle atrophy following hindlimb unloading. J. Physiol. 2015, 593, 1981-1995. [CrossRef] [PubMed]

117. Ohsumi, Y. Historical landmarks of autophagy research. Cell Res. 2014, 24, 9-23. [CrossRef] [PubMed]

118. Lemasters, J.J. Selective mitochondrial autophagy, or mitophagy, as a targeted defense against oxidative stress, mitochondrial dysfunction, and aging. Rejuvenation Res. 2005, 8, 3-5. [CrossRef] [PubMed]

119. Deng, H.; Dodson, M.W.; Huang, H.; Guo, M. The Parkinson's disease genes pink1 and parkin promote mitochondrial fission and/or inhibit fusion in Drosophila. Proc. Natl. Acad. Sci. USA 2008, 105, 14503-14508. [CrossRef] [PubMed]

120. Youle, R.J.; Narendra, D.P. Mechanisms of mitophagy. Nat. Rev. Mol. Cell Biol. 2011, 12, 9-14. [CrossRef] [PubMed]

121. Sandoval, H.; Thiagarajan, P.; Dasgupta, S.K.; Schumacher, A.; Prchal, J.T.; Chen, M.; Wang, J. Essential role for Nix in autophagic maturation of erythroid cells. Nature 2008, 454, 232-235. [CrossRef] [PubMed]

122. Liu, L.; Feng, D.; Chen, G.; Chen, M.; Zheng, Q.; Song, P.; Ma, Q.; Zhu, C.; Wang, R.; Qi, W.; et al. Mitochondrial outer-membrane protein FUNDC1 mediates hypoxia-induced mitophagy in mammalian cells. Nat. Cell Biol. 2012, 14, 177-185. [CrossRef] [PubMed]

123. Murakawa, T.; Yamaguchi, O.; Hashimoto, A.; Hikoso, S.; Takeda, T.; Oka, T.; Yasui, H.; Ueda, H.; Akazawa, Y.; Nakayama, H.; et al. Bcl-2-like protein 13 is a mammalian Atg32 homologue that mediates mitophagy and mitochondrial fragmentation. Nat. Commun. 2015, 6, 7527. [CrossRef] [PubMed]

124. Strappazzon, F.; Nazio, F.; Corrado, M.; Cianfanelli, V.; Romagnoli, A.; Fimia, G.M.; Campello, S.; Nardacci, R.; Piacentini, M.; Campanella, M.; et al. AMBRA1 is able to induce mitophagy via LC3 binding, regardless of PARKIN and p62/SQSTM1. Cell Death Differ. 2015, 22, 419-432. [CrossRef] [PubMed]

125. Lazarou, M.; Sliter, D.A.; Kane, L.A.; Sarraf, S.A.; Wang, C.; Burman, J.L.; Sideris, D.P.; Fogel, A.I.; Youle, R.J. The ubiquitin kinase PINK1 recruits autophagy receptors to induce mitophagy. Nature 2015, 524, 309-314. [CrossRef] [PubMed]

126. Song, W.H.; Yi, Y.J.; Sutovsky, M.; Meyers, S.; Sutovsky, P. Autophagy and ubiquitin-proteasome system contribute to sperm mitophagy after mammalian fertilization. Proc. Natl. Acad. Sci. USA 2016, 113, E5261-E5270. [CrossRef] [PubMed]

127. Sun, N.; Yun, J.; Liu, J.; Malide, D.; Liu, C.; Rovira, I.I.; Holmstrom, K.M.; Fergusson, M.M.; Yoo, Y.H.; Combs, C.A.; et al. Measuring in vivo mitophagy. Mol. Cell 2015, 60, 685-696. [CrossRef] [PubMed]

128. Narendra, D.P.; Jin, S.M.; Tanaka, A.; Suen, D.F.; Gautier, C.A.; Shen, J.; Cookson, M.R.; Youle, R.J. PINK1 is selectively stabilized on impaired mitochondria to activate parkin. PLoS Biol. 2010, 8, e1000298. [CrossRef] [PubMed]

129. Kane, L.A.; Lazarou, M.; Fogel, A.I.; Li, Y.; Yamano, K.; Sarraf, S.A.; Banerjee, S.; Youle, R.J. PINK1 phosphorylates ubiquitin to activate Parkin E3 ubiquitin ligase activity. J. Cell Biol. 2014, 205, 143-153. [CrossRef] [PubMed]

130. Koyano, F.; Okatsu, K.; Kosako, H.; Tamura, Y.; Go, E.; Kimura, M.; Kimura, Y.; Tsuchiya, H.; Yoshihara, H.; Hirokawa, T.; et al. Ubiquitin is phosphorylated by PINK1 to activate parkin. Nature 2014, 510, 162-166. [CrossRef] [PubMed]

131. Durcan, T.M.; Tang, M.Y.; Perusse, J.R.; Dashti, E.A.; Aguileta, M.A.; McLelland, G.L.; Gros, P.; Shaler, T.A.; Faubert, D.; Coulombe, B.; et al. USP8 regulates mitophagy by removing K6-linked ubiquitin conjugates from parkin. EMBO J. 2014, 33, 2473-2491. [CrossRef] [PubMed] 
132. Valente, E.M.; Abou-Sleiman, P.M.; Caputo, V.; Muqit, M.M.; Harvey, K.; Gispert, S.; Ali, Z.; Del Turco, D.; Bentivoglio, A.R.; Healy, D.G.; et al. Hereditary early-onset Parkinson's disease caused by mutations in PINK1. Science 2004, 304, 1158-1160. [CrossRef] [PubMed]

133. Kitada, T.; Asakawa, S.; Hattori, N.; Matsumine, H.; Yamamura, Y.; Minoshima, S.; Yokochi, M.; Mizuno, Y.; Shimizu, N. Mutations in the parkin gene cause autosomal recessive juvenile parkinsonism. Nature 1998, 392, 605-608. [PubMed]

134. Gautier, C.A.; Kitada, T.; Shen, J. Loss of PINK1 causes mitochondrial functional defects and increased sensitivity to oxidative stress. Proc. Natl. Acad. Sci. USA 2008, 105, 11364-11369. [CrossRef] [PubMed]

135. Palacino, J.J.; Sagi, D.; Goldberg, M.S.; Krauss, S.; Motz, C.; Wacker, M.; Klose, J.; Shen, J. Mitochondrial dysfunction and oxidative damage in parkin-deficient mice. J Biol Chem 2004, 279, 18614-18622. [CrossRef] [PubMed]

136. Perez, F.A.; Palmiter, R.D. Parkin-deficient mice are not a robust model of parkinsonism. Proc. Natl. Acad. Sci. USA 2005, 102, 2174-2179. [CrossRef] [PubMed]

137. Pickrell, A.M.; Huang, C.H.; Kennedy, S.R.; Ordureau, A.; Sideris, D.P.; Hoekstra, J.G.; Harper, J.W.; Youle, R.J. Endogenous parkin preserves dopaminergic substantia nigral neurons following mitochondrial DNA mutagenic stress. Neuron 2015, 87, 371-381. [CrossRef] [PubMed]

138. Twig, G.; Elorza, A.; Molina, A.J.; Mohamed, H.; Wikstrom, J.D.; Walzer, G.; Stiles, L.; Haigh, S.E.; Katz, S.; Las, G.; et al. Fission and selective fusion govern mitochondrial segregation and elimination by autophagy. EMBO J. 2008, 27, 433-446. [CrossRef] [PubMed]

139. Ikeda, Y.; Shirakabe, A.; Maejima, Y.; Zhai, P.; Sciarretta, S.; Toli, J.; Nomura, M.; Mihara, K.; Egashira, K.; Ohishi, M.; et al. Endogenous Drp1 mediates mitochondrial autophagy and protects the heart against energy stress. Circ. Res. 2015, 116, 264-278. [CrossRef] [PubMed]

140. Shirakabe, A.; Zhai, P.; Ikeda, Y.; Saito, T.; Maejima, Y.; Hsu, C.P.; Nomura, M.; Egashira, K.; Levine, B.; Sadoshima, J. Drp1-dependent mitochondrial autophagy plays a protective role against pressure overload-induced mitochondrial dysfunction and heart failure. Circulation 2016, 133, 1249-1263. [CrossRef] [PubMed]

141. Burman, J.L.; Pickles, S.; Wang, C.; Sekine, S.; Vargas, J.N.S.; Zhang, Z.; Youle, A.M.; Nezich, C.L.; Wu, X.; Hammer, J.A.; et al. Mitochondrial fission facilitates the selective mitophagy of protein aggregates. J. Cell Biol. 2017, 216, 3231-3247. [CrossRef] [PubMed]

142. Gegg, M.E.; Cooper, J.M.; Chau, K.Y.; Rojo, M.; Schapira, A.H.; Taanman, J.W. Mitofusin 1 and mitofusin 2 are ubiquitinated in a PINK1/parkin-dependent manner upon induction of mitophagy. Hum. Mol. Genet. 2010, 19, 4861-4870. [CrossRef] [PubMed]

143. Poole, A.C.; Thomas, R.E.; Yu, S.; Vincow, E.S.; Pallanck, L. The mitochondrial fusion-promoting factor mitofusin is a substrate of the PINK1/parkin pathway. PLoS ONE 2010, 5, e10054. [CrossRef] [PubMed]

144. Scarpulla, R.C.; Vega, R.B.; Kelly, D.P. Transcriptional integration of mitochondrial biogenesis. Trends Endocrinol. Metab. 2012, 23, 459-466. [CrossRef] [PubMed]

145. Lin, J.; Handschin, C.; Spiegelman, B.M. Metabolic control through the PGC-1 family of transcription coactivators. Cell Metab. 2005, 1, 361-370. [CrossRef] [PubMed]

146. Scarpulla, R.C. Nuclear control of respiratory chain expression by nuclear respiratory factors and PGC-1-related coactivator. Ann. N. Y. Acad. Sci. 2008, 1147, 321-334. [CrossRef] [PubMed]

147. Ploumi, C.; Daskalaki, I.; Tavernarakis, N. Mitochondrial biogenesis and clearance: A balancing act. FEBS J. 2017, 284, 183-195. [CrossRef] [PubMed]

148. Chowanadisai, W.; Bauerly, K.A.; Tchaparian, E.; Wong, A.; Cortopassi, G.A.; Rucker, R.B. Pyrroloquinoline quinone stimulates mitochondrial biogenesis through cAMP response element-binding protein phosphorylation and increased PGC-1 $\alpha$ expression. J. Biol. Chem. 2010, 285, 142-152. [CrossRef] [PubMed]

149. Cherra, S.J., 3rd; Kulich, S.M.; Uechi, G.; Balasubramani, M.; Mountzouris, J.; Day, B.W.; Chu, C.T. Regulation of the autophagy protein LC3 by phosphorylation. J. Cell Biol. 2010, 190, 533-539. [CrossRef] [PubMed]

150. Cuervo, A.M. Cell biology. Autophagy's top chef. Science 2011, 332, 1392-1393. [CrossRef] [PubMed]

151. Settembre, C.; Di Malta, C.; Polito, V.A.; Garcia Arencibia, M.; Vetrini, F.; Erdin, S.; Erdin, S.U.; Huynh, T.; Medina, D.; Colella, P.; et al. TFEB links autophagy to lysosomal biogenesis. Science 2011, 332, 1429-1433. [CrossRef] [PubMed] 
152. Scott, I.; Webster, B.R.; Chan, C.K.; Okonkwo, J.U.; Han, K.; Sack, M.N. GCN5-like protein 1 (GCN5L1) controls mitochondrial content through coordinated regulation of mitochondrial biogenesis and mitophagy. J. Biol. Chem. 2014, 289, 2864-2872. [CrossRef] [PubMed]

153. Alers, S.; Loffler, A.S.; Wesselborg, S.; Stork, B. Role of AMPK-mTOR-Ulk1/2 in the regulation of autophagy: Cross talk, shortcuts, and feedbacks. Mol. Cell. Biol. 2012, 32, 2-11. [CrossRef] [PubMed]

154. Tian, W.; Li, W.; Chen, Y.; Yan, Z.; Huang, X.; Zhuang, H.; Zhong, W.; Wu, W.; Lin, C.; Chen, H.; et al. Phosphorylation of ULK1 by AMPK regulates translocation of ULK1 to mitochondria and mitophagy. FEBS Lett. 2015, 589, 1847-1854. [CrossRef] [PubMed]

155. Rodgers, J.T.; Lerin, C.; Haas, W.; Gygi, S.P.; Spiegelman, B.M.; Puigserver, P. Nutrient control of glucose homeostasis through a complex of PGC-1 $\alpha$ and SIRT1. Nature 2005, 434, 113-118. [CrossRef] [PubMed]

156. Akimoto, T.; Pohnert, S.C.; Li, P.; Zhang, M.; Gumbs, C.; Rosenberg, P.B.; Williams, R.S.; Yan, Z. Exercise stimulates $\operatorname{Pg}_{\mathcal{C}-1} \alpha$ transcription in skeletal muscle through activation of the p38 MAPK pathway. J. Biol. Chem. 2005, 280, 19587-19593. [CrossRef] [PubMed]

157. Hirota, Y.; Yamashita, S.; Kurihara, Y.; Jin, X.; Aihara, M.; Saigusa, T.; Kang, D.; Kanki, T. Mitophagy is primarily due to alternative autophagy and requires the MAPK1 and MAPK14 signaling pathways. Autophagy 2015, 11, 332-343. [CrossRef] [PubMed]

158. Komatsu, M.; Waguri, S.; Chiba, T.; Murata, S.; Iwata, J.; Tanida, I.; Ueno, T.; Koike, M.; Uchiyama, Y.; Kominami, E.; et al. Loss of autophagy in the central nervous system causes neurodegeneration in mice. Nature 2006, 441, 880-884. [CrossRef] [PubMed]

159. Rubinsztein, D.C.; Marino, G.; Kroemer, G. Autophagy and aging. Cell 2011, 146, 682-695. [CrossRef] [PubMed]

160. Menzies, F.M.; Fleming, A.; Rubinsztein, D.C. Compromised autophagy and neurodegenerative diseases. Nat. Rev. Neurosci. 2015, 16, 345-357. [CrossRef] [PubMed]

161. Palikaras, K.; Daskalaki, I.; Markaki, M.; Tavernarakis, N. Mitophagy and age-related pathologies: Development of new therapeutics by targeting mitochondrial turnover. Pharmacol. Ther. 2017, 178, 157-174. [CrossRef] [PubMed]

162. Bender, A.; Krishnan, K.J.; Morris, C.M.; Taylor, G.A.; Reeve, A.K.; Perry, R.H.; Jaros, E.; Hersheson, J.S.; Betts, J.; Klopstock, T.; et al. High levels of mitochondrial DNA deletions in substantia nigra neurons in aging and Parkinson disease. Nat. Genet. 2006, 38, 515-517. [CrossRef] [PubMed]

163. Ye, X.; Sun, X.; Starovoytov, V.; Cai, Q. Parkin-mediated mitophagy in mutant hAPP neurons and Alzheimer's disease patient brains. Hum. Mol. Genet. 2015, 24, 2938-2951. [CrossRef] [PubMed]

164. Cui, L.; Jeong, H.; Borovecki, F.; Parkhurst, C.N.; Tanese, N.; Krainc, D. Transcriptional repression of PGC-1 $\alpha$ by mutant huntingtin leads to mitochondrial dysfunction and neurodegeneration. Cell 2006, 127, 59-69. [CrossRef] [PubMed]

165. Khalil, B.; El Fissi, N.; Aouane, A.; Cabirol-Pol, M.J.; Rival, T.; Lievens, J.C. PINK1-induced mitophagy promotes neuroprotection in huntington's disease. Cell Death Dis. 2015, 6, e1617. [CrossRef] [PubMed]

166. Bingol, B.; Tea, J.S.; Phu, L.; Reichelt, M.; Bakalarski, C.E.; Song, Q.; Foreman, O.; Kirkpatrick, D.S.; Sheng, M. The mitochondrial deubiquitinase USP30 opposes parkin-mediated mitophagy. Nature 2014, 510, 370-375. [CrossRef] [PubMed]

167. Carnio, S.; LoVerso, F.; Baraibar, M.A.; Longa, E.; Khan, M.M.; Maffei, M.; Reischl, M.; Canepari, M.; Loefler, S.; Kern, H.; et al. Autophagy impairment in muscle induces neuromuscular junction degeneration and precocious aging. Cell Rep. 2014, 8, 1509-1521. [CrossRef] [PubMed]

168. Joseph, A.M.; Adhihetty, P.J.; Wawrzyniak, N.R.; Wohlgemuth, S.E.; Picca, A.; Kujoth, G.C.; Prolla, T.A.; Leeuwenburgh, C. Dysregulation of mitochondrial quality control processes contribute to sarcopenia in a mouse model of premature aging. PLoS ONE 2013, 8, e69327. [CrossRef] [PubMed]

169. Nakai, A.; Yamaguchi, O.; Takeda, T.; Higuchi, Y.; Hikoso, S.; Taniike, M.; Omiya, S.; Mizote, I.; Matsumura, Y.; Asahi, M.; et al. The role of autophagy in cardiomyocytes in the basal state and in response to hemodynamic stress. Nat. Med. 2007, 13, 619-624. [CrossRef] [PubMed]

170. Billia, F.; Hauck, L.; Konecny, F.; Rao, V.; Shen, J.; Mak, T.W. PTEN-inducible kinase 1 (PINK1)/Park6 is indispensable for normal heart function. Proc. Natl. Acad. Sci. USA 2011, 108, 9572-9577. [CrossRef] [PubMed] 
171. Kubli, D.A.; Zhang, X.; Lee, Y.; Hanna, R.A.; Quinsay, M.N.; Nguyen, C.K.; Jimenez, R.; Petrosyan, S.; Murphy, A.N.; Gustafsson, A.B. Parkin protein deficiency exacerbates cardiac injury and reduces survival following myocardial infarction. J. Biol. Chem. 2013b, 288, 915-926. [CrossRef] [PubMed]

172. Kubli, D.A.; Quinsay, M.N.; Gustafsson, A.B. Parkin deficiency results in accumulation of abnormal mitochondria in aging myocytes. Commun. Integr. Biol. 2013, 6, e24511. [CrossRef] [PubMed]

173. Pisano, A.; Cerbelli, B.; Perli, E.; Pelullo, M.; Bargelli, V.; Preziuso, C.; Mancini, M.; He, L.; Bates, M.G.; Lucena, J.R.; et al. Impaired mitochondrial biogenesis is a common feature to myocardial hypertrophy and end-stage ischemic heart failure. Cardiovasc. Pathol. 2016, 25, 103-112. [CrossRef] [PubMed]

174. Hoppins, S.; Nunnari, J. Cell biology. Mitochondrial dynamics and apoptosis-The ER connection. Science 2012, 337, 1052-1054. [CrossRef] [PubMed]

175. Baker, M.J.; Palmer, C.S.; Stojanovski, D. Mitochondrial protein quality control in health and disease. Br. J. Pharmacol. 2014, 171, 1870-1889. [CrossRef] [PubMed]

176. Frank, S.; Gaume, B.; Bergmann-Leitner, E.S.; Leitner, W.W.; Robert, E.G.; Catez, F.; Smith, C.L.; Youle, R.J. The role of dynamin-related protein 1, a mediator of mitochondrial fission, in apoptosis. Dev. Cell 2001, 1, 515-525. [CrossRef]

177. Suen, D.F.; Norris, K.L.; Youle, R.J. Mitochondrial dynamics and apoptosis. Genes Dev. 2008, 22, $1577-1590$. [CrossRef] [PubMed]

178. Lee, Y.J.; Jeong, S.Y.; Karbowski, M.; Smith, C.L.; Youle, R.J. Roles of the mammalian mitochondrial fission and fusion mediators Fis1, Drp1, and Opa1 in apoptosis. Mol. Biol. Cell 2004, 15, 5001-5011. [CrossRef] [PubMed]

179. Montessuit, S.; Somasekharan, S.P.; Terrones, O.; Lucken-Ardjomande, S.; Herzig, S.; Schwarzenbacher, R.; Manstein, D.J.; Bossy-Wetzel, E.; Basanez, G.; Meda, P.; et al. Membrane remodeling induced by the dynamin-related protein Drp1 stimulates Bax oligomerization. Cell 2010, 142, 889-901. [CrossRef] [PubMed]

180. Maiuri, M.C.; Zalckvar, E.; Kimchi, A.; Kroemer, G. Self-eating and self-killing: Crosstalk between autophagy and apoptosis. Nat. Rev. Mol. Cell Biol. 2007, 8, 741-752. [CrossRef] [PubMed]

181. Baker, B.M.; Haynes, C.M. Mitochondrial protein quality control during biogenesis and aging. Trends Biochem. Sci. 2011, 36, 254-261. [CrossRef] [PubMed]

182. Powers, E.T.; Morimoto, R.I.; Dillin, A.; Kelly, J.W.; Balch, W.E. Biological and chemical approaches to diseases of proteostasis deficiency. Annu. Rev. Biochem. 2009, 78, 959-991. [CrossRef] [PubMed]

183. Koga, H.; Kaushik, S.; Cuervo, A.M. Protein homeostasis and aging: The importance of exquisite quality control. Ageing Res. Rev. 2011, 10, 205-215. [CrossRef] [PubMed]

184. Bota, D.A.; Davies, K.J. Mitochondrial Lon protease in human disease and aging: Including an etiologic classification of Lon-related diseases and disorders. Free Radic. Biol. Med. 2016, 100, 188-198. [CrossRef] [PubMed]

185. Taylor, R.C.; Dillin, A. Aging as an event of proteostasis collapse. Cold Spring Harb. Perspect. Biol. $2011,3$. [CrossRef] [PubMed]

186. Tower, J. Programmed cell death in aging. Ageing Res. Rev. 2015, 23, 90-100. [CrossRef] [PubMed]

187. Shen, J.; Tower, J. Programmed cell death and apoptosis in aging and life span regulation. Discov. Med. 2009, 8, 223-226. [PubMed]

188. Marchi, S.; Giorgi, C.; Suski, J.M.; Agnoletto, C.; Bononi, A.; Bonora, M.; De Marchi, E.; Missiroli, S.; Patergnani, S.; Poletti, F.; et al. Mitochondria-Ros crosstalk in the control of cell death and aging. J. Signal Transduct. 2012, 2012, 329635. [CrossRef] [PubMed]

189. Smaili, S.S.; Pereira, G.J.; Costa, M.M.; Rocha, K.K.; Rodrigues, L.; do Carmo, L.G.; Hirata, H.; Hsu, Y.T. The role of calcium stores in apoptosis and autophagy. Curr. Mol. Med. 2013, 13, 252-265. [CrossRef] [PubMed]

190. Tezil, T.; Basaga, H. Modulation of cell death in age-related diseases. Curr. Pharm. Des. 2014, 20, 3052-3067. [CrossRef] [PubMed]

191. Arnould, T.; Michel, S.; Renard, P. Mitochondria retrograde signaling and the UPR ${ }^{\mathrm{mt}}$. Where are we in mammals? Int. J. Mol. Sci. 2015, 16, 18224-18251. [CrossRef] [PubMed]

192. Jazwinski, S.M.; Kriete, A. The yeast retrograde response as a model of intracellular signaling of mitochondrial dysfunction. Front. Physiol. 2012, 3, 139. [CrossRef] [PubMed]

193. Andreux, P.A.; Houtkooper, R.H.; Auwerx, J. Pharmacological approaches to restore mitochondrial function. Nat. Rev. Drug Discov. 2013, 12, 465-483. [CrossRef] [PubMed] 
194. Jazwinski, S.M. The retrograde response: When mitochondrial quality control is not enough. Biochim. Biophys. Acta 2013, 1833, 400-409. [CrossRef] [PubMed]

195. Ristow, M.; Schmeisser, K. Mitohormesis: Promoting health and lifespan by increased levels of reactive oxygen species (ROS). Dose Response 2014, 12, 288-341. [CrossRef] [PubMed]

196. Schmeisser, S.; Schmeisser, K.; Weimer, S.; Groth, M.; Priebe, S.; Fazius, E.; Kuhlow, D.; Pick, D.; Einax, J.W.; Guthke, R.; et al. Mitochondrial hormesis links low-dose arsenite exposure to lifespan extension. Aging Cell 2013, 12, 508-517. [CrossRef] [PubMed]

197. Weimer, S.; Priebs, J.; Kuhlow, D.; Groth, M.; Priebe, S.; Mansfeld, J.; Merry, T.L.; Dubuis, S.; Laube, B.; Pfeiffer, A.F.; et al. D-Glucosamine supplementation extends life span of nematodes and of ageing mice. Nat. Commun. 2014, 5, 3563. [CrossRef] [PubMed]

198. Jovaisaite, V.; Auwerx, J. The mitochondrial unfolded protein response-synchronizing genomes. Curr. Opin. Cell Biol. 2015, 33, 74-81. [CrossRef] [PubMed]

199. Durieux, J.; Wolff, S.; Dillin, A. The cell-non-autonomous nature of electron transport chain-mediated longevity. Cell 2011, 144, 79-91. [CrossRef] [PubMed]

200. Lee, M.S. Effect of mitochondrial stress on systemic metabolism. Ann. N. Y. Acad. Sci. 2015, 1350, 61-65. [CrossRef] [PubMed]

201. Fujita, Y.; Ito, M.; Kojima, T.; Yatsuga, S.; Koga, Y.; Tanaka, M. GDF15 is a novel biomarker to evaluate efficacy of pyruvate therapy for mitochondrial diseases. Mitochondrion 2015, 20,34-42. [CrossRef] [PubMed]

202. Madeo, F.; Tavernarakis, N.; Kroemer, G. Can autophagy promote longevity? Nat. Cell Biol. 2010, 12, 842-846. [CrossRef] [PubMed]

203. Rana, A.; Rera, M.; Walker, D.W. Parkin overexpression during aging reduces proteotoxicity, alters mitochondrial dynamics, and extends lifespan. Proc. Natl. Acad. Sci. USA 2013, 110, 8638-8643. [CrossRef] [PubMed]

204. Ryu, D.; Mouchiroud, L.; Andreux, P.A.; Katsyuba, E.; Moullan, N.; Nicolet-Dit-Felix, A.A.; Williams, E.G.; Jha, P.; Lo Sasso, G.; Huzard, D.; et al. Urolithin A induces mitophagy and prolongs lifespan in C. Elegans and increases muscle function in rodents. Nat. Med. 2016, 22, 879-888. [CrossRef] [PubMed]

205. Baur, J.A.; Pearson, K.J.; Price, N.L.; Jamieson, H.A.; Lerin, C.; Kalra, A.; Prabhu, V.V.; Allard, J.S.; Lopez-Lluch, G.; Lewis, K.; et al. Resveratrol improves health and survival of mice on a high-calorie diet. Nature 2006, 444, 337-342. [CrossRef] [PubMed]

206. LaRocca, T.J.; Gioscia-Ryan, R.A.; Hearon, C.M., Jr.; Seals, D.R. The autophagy enhancer spermidine reverses arterial aging. Mech. Ageing Dev. 2013, 134, 314-320. [CrossRef] [PubMed]

207. Gomes, A.P.; Price, N.L.; Ling, A.J.; Moslehi, J.J.; Montgomery, M.K.; Rajman, L.; White, J.P.; Teodoro, J.S.; Wrann, C.D.; Hubbard, B.P.; et al. Declining NAD ${ }^{+}$induces a pseudohypoxic state disrupting nuclear-mitochondrial communication during aging. Cell 2013, 155, 1624-1638. [CrossRef] [PubMed]

208. Hepple, R.T.; Baker, D.J.; McConkey, M.; Murynka, T.; Norris, R. Caloric restriction protects mitochondrial function with aging in skeletal and cardiac muscles. Rejuvenation Res. 2006, 9, 219-222. [CrossRef] [PubMed]

209. Song, W.; Kwak, H.B.; Lawler, J.M. Exercise training attenuates age-induced changes in apoptotic signaling in rat skeletal muscle. Antioxid. Redox Signal. 2006, 8, 517-528. [CrossRef] [PubMed]

210. Picca, A.; Pesce, V.; Fracasso, F.; Joseph, A.M.; Leeuwenburgh, C.; Lezza, A.M. Aging and calorie restriction oppositely affect mitochondrial biogenesis through TFAM binding at both origins of mitochondrial DNA replication in rat liver. PLOS ONE 2013, 8, e74644. [CrossRef] [PubMed]

211. Srivastava, S.; Haigis, M.C. Role of sirtuins and calorie restriction in neuroprotection: Implications in Alzheimer's and Parkinson's diseases. Curr. Pharm. Des. 2011, 17, 3418-3433. [CrossRef] [PubMed]

212. Galluzzi, L.; Pietrocola, F.; Levine, B.; Kroemer, G. Metabolic control of autophagy. Cell 2014, 159, $1263-1276$. [CrossRef] [PubMed]

213. Madeo, F.; Zimmermann, A.; Maiuri, M.C.; Kroemer, G. Essential role for autophagy in life span extension. J. Clin. Investig. 2015, 125, 85-93. [CrossRef] [PubMed]

214. Lewis, G.D.; Farrell, L.; Wood, M.J.; Martinovic, M.; Arany, Z.; Rowe, G.C.; Souza, A.; Cheng, S.; McCabe, E.L.; Yang, E.; et al. Metabolic signatures of exercise in human plasma. Sci. Transl. Med. 2010, 2. [CrossRef] [PubMed]

215. Suwa, M.; Sakuma, K. The potential role of sirtuins regarding the effects of exercise on aging-related diseases. Curr. Aging Sci. 2013, 6, 178-188. [CrossRef] [PubMed] 
216. Moreira, O.C.; Estebanez, B.; Martinez-Florez, S.; de Paz, J.A.; Cuevas, M.J.; Gonzalez-Gallego, J. Mitochondrial function and mitophagy in the elderly: Effects of exercise. Oxid. Med. Cell. Longev. 2017, 2017, 2012798. [CrossRef] [PubMed]

217. Johnson, S.C.; Rabinovitch, P.S.; Kaeberlein, M. mTOR is a key modulator of ageing and age-related disease. Nature 2013, 493, 338-345. [CrossRef] [PubMed]

218. Martin-Montalvo, A.; Mercken, E.M.; Mitchell, S.J.; Palacios, H.H.; Mote, P.L.; Scheibye-Knudsen, M.; Gomes, A.P.; Ward, T.M.; Minor, R.K.; Blouin, M.J.; et al. Metformin improves healthspan and lifespan in mice. Nat. Commun. 2013, 4, 2192. [CrossRef] [PubMed]

219. Raffaello, A.; Rizzuto, R. Mitochondrial longevity pathways. Biochim. Biophys. Acta 2011, 1813, $260-268$. [CrossRef] [PubMed]

220. Burkewitz, K.; Weir, H.J.; Mair, W.B. AMPK as a pro-longevity target. EXS 2016, 107, 227-256. [PubMed]

221. Kenyon, C.J. The genetics of ageing. Nature 2010, 464, 504-512. [CrossRef] [PubMed]

222. Martina, J.A.; Chen, Y.; Gucek, M.; Puertollano, R. MTORC1 functions as a transcriptional regulator of autophagy by preventing nuclear transport of TFEB. Autophagy 2012, 8, 903-914. [CrossRef] [PubMed]

223. Lapierre, L.R.; Kumsta, C.; Sandri, M.; Ballabio, A.; Hansen, M. Transcriptional and epigenetic regulation of autophagy in aging. Autophagy 2015, 11, 867-880. [CrossRef] [PubMed]

224. Zhang, C.S.; Lin, S.C. AMPK promotes autophagy by facilitating mitochondrial fission. Cell Metab. 2016, 23, 399-401. [CrossRef] [PubMed]

225. Ristow, M.; Zarse, K. How increased oxidative stress promotes longevity and metabolic health: The concept of mitochondrial hormesis (mitohormesis). Exp. Gerontol. 2010, 45, 410-418. [CrossRef] [PubMed]

226. Balch, W.E.; Morimoto, R.I.; Dillin, A.; Kelly, J.W. Adapting proteostasis for disease intervention. Science 2008, 319, 916-919. [CrossRef] [PubMed]

(C) 2017 by the author. Licensee MDPI, Basel, Switzerland. This article is an open access article distributed under the terms and conditions of the Creative Commons Attribution (CC BY) license (http:/ / creativecommons.org/licenses/by/4.0/). 